tow sate 


\section{GEOLOGY OF THE}

GREAT SMOKY MOUNTAINS NATIONAL PARK, TENNESSEE AND NORTH GAROLINA

By PHILIP B. KING, ROBERT B. NEUMAN, and JARVIS B. HADLEY

$\begin{array}{lllll}\text { GEOLOGICAL SURVEY PROFESSIONAL PAPER } & 587\end{array}$

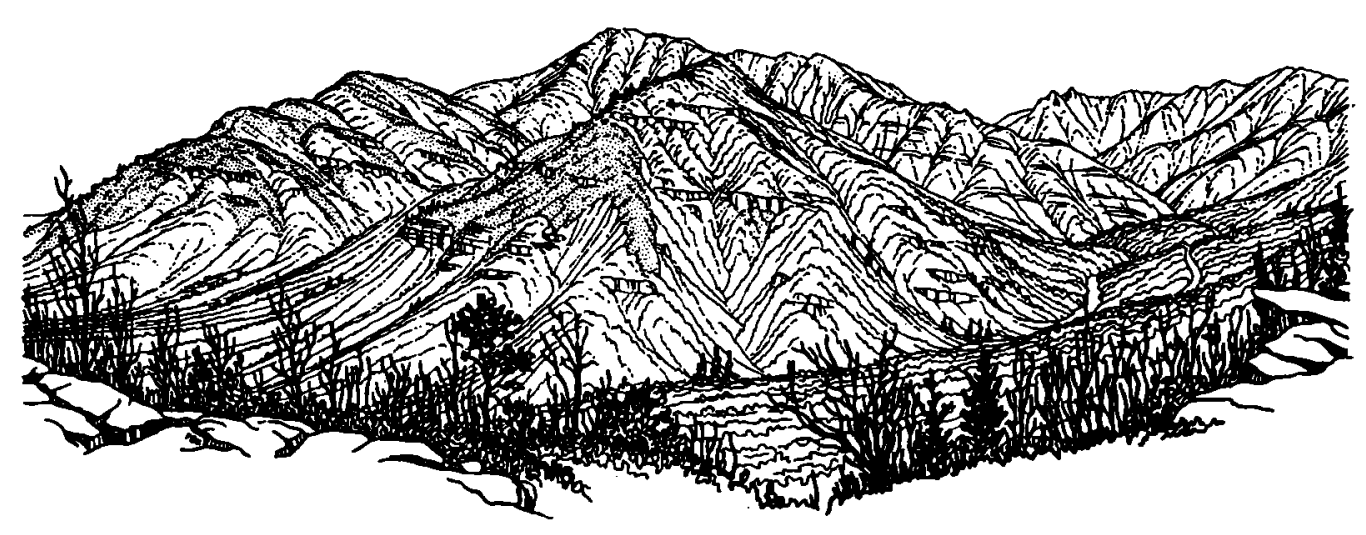

UNITED STATES GOVERNMENT PRINTING OFFICE WASHINGTON: 1968 


\section{UNITED STATES DEPARTMENT OF THE INTERIOR}

STEWART L. UDALL, Secretary

\section{GEOLOGICAL SURVEY}

William T. Pecora, Director

Library of Congress catalog-card No. GS 67-301

For sale by the Superintendent of Documents, U.S. Government Printing Office Washington, D.C. 20402 


\section{PREFACE}

Every year, thousands of our fellow Americans visit Great Smoky Mountains National Park, in the heart of the southern Appalachian highlands. All visitors find refreshment in this mountain wilderness, some of them are also inspired by its deeper meanings- by observing the varied forests and other living things of the mountains, and by contemplating the long ages of the past during which the mountains and their living things must have evolved. These past ages can be deciphered by geologic study, which interprets first of all how the land has been shaped into its present form, and more remotely, the nature and history of the rocks from which the land has been carved.

The account which follows deals primarily with this more remote part of the geologic story-the rocks which compose the mountains. How the present mountains came into being is a later chapter of the story, interesting in itself, which deserves its own presentation in another place.

The present account summarizes the results of a long investigation of the rocks of the Great Smoky Mountains (1946-55) by geologists of the staff of the U.S. Geological Survey, in collaboration with those of the Tennessee Division of Geology. The technical details of this investigation have already been set forth at length in professional papers of the U.S. Geological Survey. The present account contains the gist of these findings about the rocks of the mountains, and is accompanied by a map and structure sections in which the surface and underground extent of the rocks are displayed.

This summary, by cutting through the many technical problems involved, will be useful to students interested in geology and the other natural sciences, and to a wider audience as well. Even so, to portray adequately the rocks of the mountains and their history involves at least some recourse to geologic terminology, so that all the assertions made herein may not be comprehensible to the general reader. As an aid to the reader, a glossary of the geologic terms used is therefore included at the end. For those readers who desire more detailed information regarding the findings so briefly summarized in this account, reference should be made to the more lengthy professional papers on which the account is based. 
Cover:

\section{VIEW OF MOUNT LE CONTE EASTWARD ACROSS VALLEY OF WEST PRONG OF LITTLE PIGEON RIVER FROM SUGARLAND MOUNTAIN}

View encompasses most of the formations of the Great Smoky Group of the Ocoee Series and much of its thickness as well. The ledges and cliffs are Thunderhead Sandstone, here about 7,000 feet thick; beneath them at the base of slope on the left, the Elkmont Sandstone emerges; the Anakeesta Formation caps Mount Le Conte (the background peake right of center of view) and forms the jagged peaks of The Chimneys at the right. Drawing by Philip B. King. 


\section{CONTENTS}

Preface

\begin{tabular}{r|r} 
Page & \\
III & Structure of the bedrock \\
2 & Greenbrier and related faults \\
2 & Great Smoky and related faults \\
3 & Fotlinburg and related faults \\
4 & Summary of deformational history \\
5 & Noteworthy exposures in the area \\
6 & Glossary \\
7 & References cited \\
8 & \\
9 &
\end{tabular}

Introduction

Bedrock geology

Basement complex

Ocoee Series

Snowbird Group

Great Smoky Group

Unclassified formations of Ocoee Series

Walden Creek Group

Interpretation of Ocoee Series

Paleozoic rocks

Igneous rocks

\section{ILLUSTRATIONS}

Plate 1. Geologic map and structure sections

Figure 1. View from Cliff Top on Mount Le Conte $\ldots$

2. Little River gap................. 11

3. View of Cades Cove

4. The Great Smoky fault and related structures.

5. Geologic features at The Sinks _............. 17

6. Geologic features visible from Maloney Point $\ldots$

7. Geologic features at Chimneys Overlook ....... 20

\section{TABLES}

TABLE 1. Stratigraphic units of the Ocoee Series of the Great Smoky Mountains _ $\quad 4$

2. Paleozoic formations in the vicinity of the Great Smoky Mountains . . . . 10 



\section{GEOLOGY OF THE GREAT SMOKY MOUNTAINS NATIONAL PARK TENNESSEE AND NORTH GAROLINA}

\section{Introduction}

The boundary between Tennessee and North Carolina is delimited for about $\mathbf{5 0}$ miles in midlength by the crests of the Great Smoky Mountains, which include some of the highest summits in the southeastern United States, and which culminate in Clingmans Dome (alt 6,642 ft). Ramifying spurs and foothills descend northwestward from the State line divide toward the Appalachian Valley in Tennessee, as well as southeastward toward the less regularly disposed mountains of the main part of the Blue Ridge in North Carolina. All the Great Smoky Mountains are heavily forested, the higher summits being covered by spruce and fir, and the lower slopes, by a great variety of hardwoods. Much of this forested mountain wilderness has been set aside for public benefit and enjoyment as Great Smoky Mountains National Park.

For most visitors to Great Smoky Mountains National Park, prime attractions are its noble forests, its open coves set gemlike amongst them, the animals of the forests and coves, and the relics of the mountaineers who have made their homes there. Only now and then, when the visitor's trail through the forest must circuit a rough ledge of rock, can he realize that the forest and the soil on which it grows are a mere veneer-a thin cover over the ancient rocks of the mountains. In the Yosemite, the Grand Canyon, and most of our other national parks in the West, the situation is very different; there, the impact of the bedrock of the parks is overwhelming in relation to the plants and animals that live on the bedrock.

The terrain of the Great Smoky Mountains, their soils, unconsolidated deposits, and details of slope sculpture tell a geologic story of the last few million years of earth history, a story dominated by the drastic fluctuations of the ice-age climate. Although the mountains themselves were not covered with glacial ice, the climate at this latitude approached glacial conditions, and the mountaintops were occasionally above tree line. Deposits of debris that resulted from the associated accelerated erosion of the hillsides during glacial intervals and the deeply weathered soils produced during the episodes of warm and humid interglacial climate are evident at many places. These climatic oscillations also controlled the flora and fauna. The complex process of adjustment of plants and animals to the prevailing climate is one of the factors that has produced their present great diversity. This latest phase of the geologic history is not further treated in this publication. Maps showing the younger deposits and interpretations based on them are included in the several recent U.S. Geological Survey Professional Papers referred to below.

Our concern in this text and its accompanying map (pl. 1) is with the bedrock geology of the Great Smoky Mountains and their surroundings, and with the story of far earlier times in earth history-when there were no Great Smoky Mountains, and when the geography and the landscape were very different from those today.

Because of the forest cover and the scantiness of rock outcrops, the bedrock geology of the Great Smoky Mountains is not easy to decipher, and this difficulty is compounded by the enigmatic nature of most of the rocks themselves. It thus has come about that knowledge of the geology of the mountains has lagged behind that in surrounding regions. Following pioneer investigations of Safford (1869) and of Keith (1895, 1896), little further geologic study of the mountains was made until after World War II. The present text and map summarize the results of the more recent investigations, details of which are given at much greater length in a set of U.S. Geolog- 
ical Survey Professional Papers (Hamilton, 1961; Hadley and Goldsmith, 1963; King, 1964; Neuman and Nelson, 1965).

\section{Bedrock Geology}

Despite the enigmatic nature of the rocks of the Great Smoky Mountains, they are of more than usual geologic interest, as they link the contrasting Paleozoic sedimentary rocks of the Appalachian Valley on the northwest with the metamorphic and granitic rocks of the Blue Ridge on the southeast. Like the rocks of the Appalachian Valley, most of those in the Great Smoky Mountains are of sedimentary origin; moreover, near the Appalachian Valley these rocks are as little changed or metamorphosed as those in the valley. But unlike the latter, which are a varied sequence of fossil-bearing limestones, sandstone, and shales, those of the mountains are a great mass of pebbly, sandy, and muddy sedimentary rocks, lacking in fossil remains. Moreover, by a gradual southeastward increase of shearing, recrystallization, and metamorphism these original sediments acquire more and more the aspect of the rocks of the nearby Blue Ridge.

The intermediate nature of the rocks of the Great Smoky Mountains applies not only to their aspect but also to their age. Relations of these rocks to those adjacent indicate that the rocks of the Great Smoky Mountains were deposited later than most of the rocks of the Blue Ridge, which are of earlier Precambrian age (formed more than a billion years ago), but before the rocks of the Appalachian Valley, which are of early to middle Paleozoic age (formed 600 million to 300 million years ago). Most of the rocks of the Great Smoky Mountains were formed during some part of later Precambrian time (a billion to 600 million years ago).

The bedrock of the Great Smoky Mountains and their surroundings, and the geologic story that can be deduced from it, are thus divisible into three chapters. The metamorphic and granitic rocks characteristic of the Blue Ridge on the southeast (the basement complex) represent the first chapter of the story, that of earlier Precambrian time. The pebbly, sandy, and muddy sedimentary rocks of the Great Smoky Mountains themselves (the Ocoee Series) represent the second chapter, that of later Precambrian time. The sedimentary rocks of the Appalachian Valley represent the third chapter, that of Paleozoic time. In the succeeding account, the rocks and the events which they imply will be treated in this chronological orderwhich is also roughly their geographic order from southeast to northwest across the mountains.

\section{Basement Complex}

The rocks of the Blue Ridge, or basement complex, are the ancient much-altered crystalline foundation on which all the other strata of the region have been laid. They extend along the southeastern side of the Great Smoky Mountains and are extensively exposed in the southeastern part of the area shown on the map on each side of the Pigeon River near Waterville Lake, in the valley of Jonathan Creek, and near the villages of Dellwood and Maggie along U.S. Highway 19W. They also reappear at several places within the mountains themselves where tectonic forces have pushed them up or have thrust them into contact with younger rocks (pl. 1, structure sections $A-A^{\prime}$ and $B-B^{\prime}$. Still farther southwest they form two oval-shaped areas near Ela and Bryson City.

The basement complex consists of a wide variety of gneisses and schists, including both layered gneisses derived from sedimentary or volcanic rocks and nonlayered, mostly granitic, gneisses representing intrusive bodies. Layered gneisses are most abundant toward the southeast near Maggie and Dellwood, whereas granitic rocks are dominant in areas toward the northwest. No single type occupies large areas, however; boundary relations between the various types are both gradational and geometrically complex and cannot be shown at the scale of the present map.

The layered gneisses are foliated crystalline rocks which contain various proportions of biotite, muscovite, quartz, and feldspar. They include also minor amounts of mica schist and of gneisses that contain small to large amounts of hornblende. The identifiable rock types are intercalated in layers and lenses an inch to several tens of feet thick. The granitic rocks are somewhat less diverse in composition and are mostly quartz monzonite and granodiorite in which biotite, primary epidote, and magnetite are the chief mafic minerals. Some of the less granitic rocks range from quartz monzonite to true granite, and a few small intrusive bodies are amphibolite or pegmate. Although the granitic rocks are not conspicuously layered, most of them have flaser or augen structure resulting from their having been deformed one or more times since initial consolidation of the complex.

The basement complex has undergone so many changes that its origin and age can be stated only in the broadest terms. The mica gneiss and schist were probably sandy and shaly sediments, whereas at least some of the hornblende gneisses may have been volcanic flows or tuffs. The granitic rocks which dominate toward the northwest may have originated partly as a magma that invaded 
these rocks, but many features, including their gradational relations with the more layered rocks and their bulk chemical composition, suggest that some were converted from originally stratified rocks during deep burial and prolonged metamorphism. During Paleozoic time the basement complex underwent the same deformation and metamorphism to which the younger rocks of the region were subjected, and in many places this has obscured its relations to the younger rocks. Yet, there are many indications that it formed during an earlier geologic cycle. The structures of the basement are more complex and include not only those of Paleozoic age but also metamorphic and plutonic structural features that are lacking in the later Precambrian rocks, and hence are presumably older. Moreover, debris in the basal part of the later Precambrian sedimentary rocks can be matched with constituents of the basement complex; the debris was obviously derived from the basement surface when it was undergoing erosion.

The time at which the stratified rocks of the complex originally formed has not been determined, but the approximate time of their metamorphism and transformation is suggested by age determinations on radioactive minerals. These have yielded ages of about a billion years, as well as a scattering of younger ages down to about 350 million years (Long and others, 1959, p. 588-590; Tilton and others, 1960, p. 4173-4175; Kulp and Eckelmann, 1961; Hadley, 1964, p. 36-39). The earlier ages are believed to express the principal metamorphic and plutonic events to which the basement complex was subjected; the younger ages are believed to represent modifications of these dates by later metamorphic and plutonic events that culminated during the middle of the Paleozoic. Detrital grains from the later Precambrian sedimentary rocks of the Great Smoky Mountains have yíelded ages of 820 million to a billion years (Carroll and others, 1957, p. 186-188; Stern and Rose, 1961, p. 609 ) and express dates in the basement complex from which they were derived, rather than the age of the rocks in which they are now embedded.

\section{Ocoee Series}

The later Precambrian sedimentary rocks, which form most of the Great Smoky Mountains and large parts of the adjacent foothills, are known as the Ocoee Series after the river of that name near the southern boundary of Tennessee (Stafford, 1869, p. 183-198). The Ocoee Series extends far beyond the Great Smoky Mountains to the northeast and southwest, along the trend of the 275-339-68-2 ranges-from northeast of Asheville, N.C., at least as far as Cartersville, Ga., a distance of more than 175 miles. Near the Great Smoky Mountains this series extends across the ranges for about 30 miles, and in some other places its breadth is even greater.

Along its northwestern edge, the Ocoee Series has been thrust over the Paleozoic rocks of the Appalachian Valley along the Great Smoky fault (see under "Geologic structure"). The series has also been complexly folded and faulted internally and has been metamorphosed to varying degrees by heat and pressure. Toward the northwest the clay minerals in the sedimentary rocks have been altered to chlorite typical of low-grade metamorphic rocks; southeastward these minerals have been transformed to biotite and garnet typical of medium-grade metamorphic rocks; farthest southeast these minerals are represented by staurolite and kyanite typical of higher grade metamorphic rocks. Rocks with dominant clay minerals thus change southeastward from shales to slates, and these into phyllites and schists. Nevertheless, metamorphic grain sizes are smaller, and obliteration of sedimentary structures is less than in similarly metamorphosed rocks in many regions. Sandstones are recrystallized and their grain sizes modified, but their bedding and other sedimentary structures are clearly preserved nearly everywhere. It is thus convenient in this account to refer to the rocks of the Ocoee Series largely in terms of their original sedimentary nature, rather than in terms of their present metamorphic condition which varies from one part of the mountains to another. Some degree of metamorphism can be assumed for nearly all the rocks of the Ocoee Series.

Throughout great thicknesses, the rocks of the Ocoee Series are of monotonous aspect, with a few types repeated or interbedded, and with the grosser units lensing or grading into one another. Where abrupt contacts are visible between different gross units, these generally have been faulted together. Although the rocks of the Ocoee Series are broadly akin in age and origin, the series includes several differing parts called the Snowbird, Great Smoky, and Walden Creek Groups (King and others 1958, p. 951-954; table 1).

In general, the Great Smoky Group is most widespread toward the southeast, where it forms the main mass of the Great Smoky Mountains; the Snowbird Group occurs in the middle, in the foothills just north of the mountains; and the Walden Creek Group occurs toward the northwest, in the part of the foothills nearest the Appalachian Valley. To some extent, these groups form a sequence. The Snowbird Group lies on the basement complex, and 
GEOLOGY OF GREAT SMOKY MOUNTAINS NATIONAL PARK, TENNESSEE AND NORTH CAROLINA

TABLE 1.-Stratigraphic units of the Ocoee Series of the Great Smoky Mountains

\begin{tabular}{|c|c|c|c|c|c|c|c|c|}
\hline Age & \multicolumn{4}{|c|}{ North of and below Greenbrier fault } & \multirow{7}{*}{ 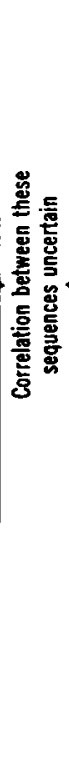 } & \multicolumn{3}{|c|}{ South of and above Greenbrier fault } \\
\hline $\begin{array}{c}\text { Cambrian(?) and } \\
\text { Cambrian }\end{array}$ & $\begin{array}{l}\text { Chilhowee } \\
\text { Group }\end{array}$ & \multicolumn{3}{|c|}{ Cochran Formation and higher units } & & \multicolumn{2}{|c|}{$\begin{array}{l}\text { Rocks of Murphy } \\
\text { marble belt }\end{array}$} & $\begin{array}{l}\text { Nantahala Slate and higher units } \\
\text { (Early Paleozoic(?)) }\end{array}$ \\
\hline \multirow[t]{3}{*}{ Later } & \multirow{3}{*}{ 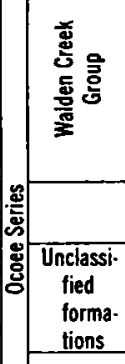 } & $\begin{array}{l}s \\
n \\
s \\
4\end{array}$ & $\begin{array}{l}\text { ndsuck Formation } \\
\text { lhite Formation } \\
\text { ields Formation } \\
\text { klog Formation }\end{array}$ & & & \multirow{4}{*}{ 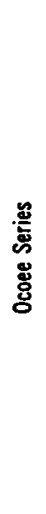 } & \multirow{3}{*}{$\begin{array}{l}\text { 흥 } \\
\text { E⿱ } \\
\text { 言 } \\
\text { 总 }\end{array}$} & $\begin{array}{l}\text { Unnamed sandstone } \\
\text { Anakeesta Formation }\end{array}$ \\
\hline & & Western part of area & $\int_{\text {Eastern part of }}$ & & & & & Thunderhead Sandstone \\
\hline & & Cades Sandstone & $\begin{array}{c}\text { Rocks of Webb Mountain } \\
\text { and Big Ridge }\end{array}$ & $\begin{array}{l}\text { Rich Butt } \\
\text { Sandstone }\end{array}$ & & & & Elkmont Sandstone \\
\hline Precambrian & 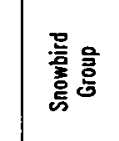 & Metcalf Phyllite & \multicolumn{2}{|c|}{$\begin{array}{l}\text { Pigeon Siltstone } \\
\text { Roaring Fork Sandstone } \\
\text { Longarm Quartzite } \\
\text { Wading Branch Formation }\end{array}$} & & & $\begin{array}{l}\text { 을 } \\
\text { 言 } \\
\text { 总 }\end{array}$ & $\begin{array}{l}\text { Roaring Fork Sandstone } \\
\text { Longarm Quartzite } \\
\text { Wading Branch Formation }\end{array}$ \\
\hline $\begin{array}{c}\text { Eartier } \\
\text { Precambrian }\end{array}$ & & & \multicolumn{2}{|c|}{ Basement complex } & & \multicolumn{3}{|r|}{ Basement complex } \\
\hline
\end{tabular}

at one place or another is overlain either by the Great Smoky Group or the Walden Creek Group. But the Snowbird Group varies markedly in thickness from one part of the Great Smoky Mountains to another, and the mutual relations between the Great Smoky and Walden Creek Groups are uncertain. Before the relations between the three groups and their probable history are interpreted the rocks of the individual groups will be described.

\section{Snowbird Group}

The most informative exposures of the Snowbird Group are east of the end of the Great Smoky Mountains, in the valley of the Pigeon River from Waterville Lake to the village of Hartford, 10 miles to the north. In the valley of the Pigeon River the Snowbird Group forms a northwestward-facing sequence about 13,000 feet thick, which lies on the basement complex near Waterville Lake and is overlain by the Rich Butt Sandstone (pl. 1, structure section $A-A^{\prime}$ ). In this area the Snowbird Group is divisible into four formations that are named, in ascending order, the Wading Branch Formation, the Longarm Quartzite, the Roaring Fork Sandstone, and the Pigeon Siltstone.

The relatively thin Wading Branch Formation, resting on granitic rocks of the basement complex, is a heterogeneous dark-colored assortment of sandy argillite, siltstone, and pebbly feldspathic sandstone. A distinctive basal argillaceous layer, now phyllitic, was probably reworked from clays that accumulated on the weathered surface of the granitic rocks. The overlying and thicker Longarm
Quartzite is dominantly light-colored medium- to coarsegrained feldspathic quartzite and arkose, many of whose layers are current bedded. Upward, the quartzite is interbedded more and more with sandstone like that in the overlying formation, the Roaring Fork Sandstone, which is darker and finer grained than the Longarm, and forms beds 5-50 feet thick. Sandstone beds of the Roaring Fork are separated by nearly equal thicknesses of argillaceous and silty rocks, mostly phyllitic. The overlying very thick Pigeon Siltstone consists of argillaceous material intermingled with abundant grains of quartz and feldspar that are much smaller than normal sand size. It forms dullgreenish massive layers that are marked throughout by light and dark laminae, straight and even bedded through great thicknesses, but with an irregular or "lenticularlaminate" structure in some parts. The Pigeon Siltstone is mostly very uniform, but in some places it contains a few beds of dark fine-grained sandstone like those in the Roaring Fork; elsewhere, carbonate-rich layers as much as 2 feet thick are present, and are made conspicuous by their rusty-weathered surfaces.

The Snowbird Group is even more extensively exposed along the north side of the Great Smoky Mountains, where it forms a belt of rugged foothills that extends as far west as Cades Cove. There, however, both its top and base are faulted off and are not visible. Moreover, the coarser formations that are well displayed along the Pigeon River fade out westward; the Longarm Quartzite intertongues with the Roaring Fork Sandstone, and the Roaring Fork intertongues with the Pigeon Siltstone. 
Thus, in the vicinity of Gatlinburg in the central part of the mountains, only the Roaring Fork Sandstone and Pigeon Siltstone are represented; nevertheless, the exposed part of the Snowbird Group here is as much as 17,000 feet thick, or thicker than all four of its formations along the Pigeon River (Hamilton, 1961, p. A9-A10; Hadley and Goldsmith, 1963, p. B33, B37). The transmountain highway (U.S. Highway 441) in its course along the West Prong of the Little Pigeon River traverses the Snowbird Group from 4 miles north of Gatlinburg to the edge of the high mountains 2 miles southeast of national park headquarters; characteristic outcrops of the Pigeon Siltstone may be seen along the highway north of Gatlinburg, and characteristic outcrops of the Roaring Fork Sandstone may be seen southeast of park headquarters.

West of the Gatlinburg area the Snowbird Group is exposed only in strips or slices that are faulted between other units of the Ocoee Series. Here, perhaps because of the faulting and the extreme shearing attendant upon it, sedimentary structures are less evident. This part of the group is termed the Metcalf Phyllite, but is probably equivalent to parts of the Pigeon Siltstone and Roaring Fork Sandstone farther east. The Metcalf is well exposed in many cuts along Tennessee Highway 73 between Elkmont and Tuckaleechee Cove, in the gorge of the main east prong of the Little River.
The Snowbird Group is also exposed in the southeastern part of the Great Smoky Mountains, adjoining the basement complex, in several narrow strips that are structurally separated from the Snowbird Group farther north. Here, characteristic rocks of the Wading Branch Formation, Longarm Quartzite, and Roaring Fork Sandstone are recognizable from one place to another; but the whole group is less than 2,000 feet thick, remarkably thinner than in the northern sequences. Moreover, from Maggie eastward, even this thinned representative of the Snowbird Group wedges out, so that the Great Smoky Group lies directly on the basement complex beyond.

\section{Great Smoky Group}

The Great Smoky Group forms the main bulk of the Great Smoky Mountains and extends their entire length, from near the Pigeon River on the east to beyond the Little Tennessee River on the west (fig. 1). It also extends across the mountains from the foothills of Snowbird Group on the north to the areas of basement complex on the southeast. In addition, many rocks in discontinuous areas in the northern foothills resemble the Great Smoky Group, but, for reasons explained on page 6 , most of these are considered to be "unclassified formations" of the Ocoee Series.

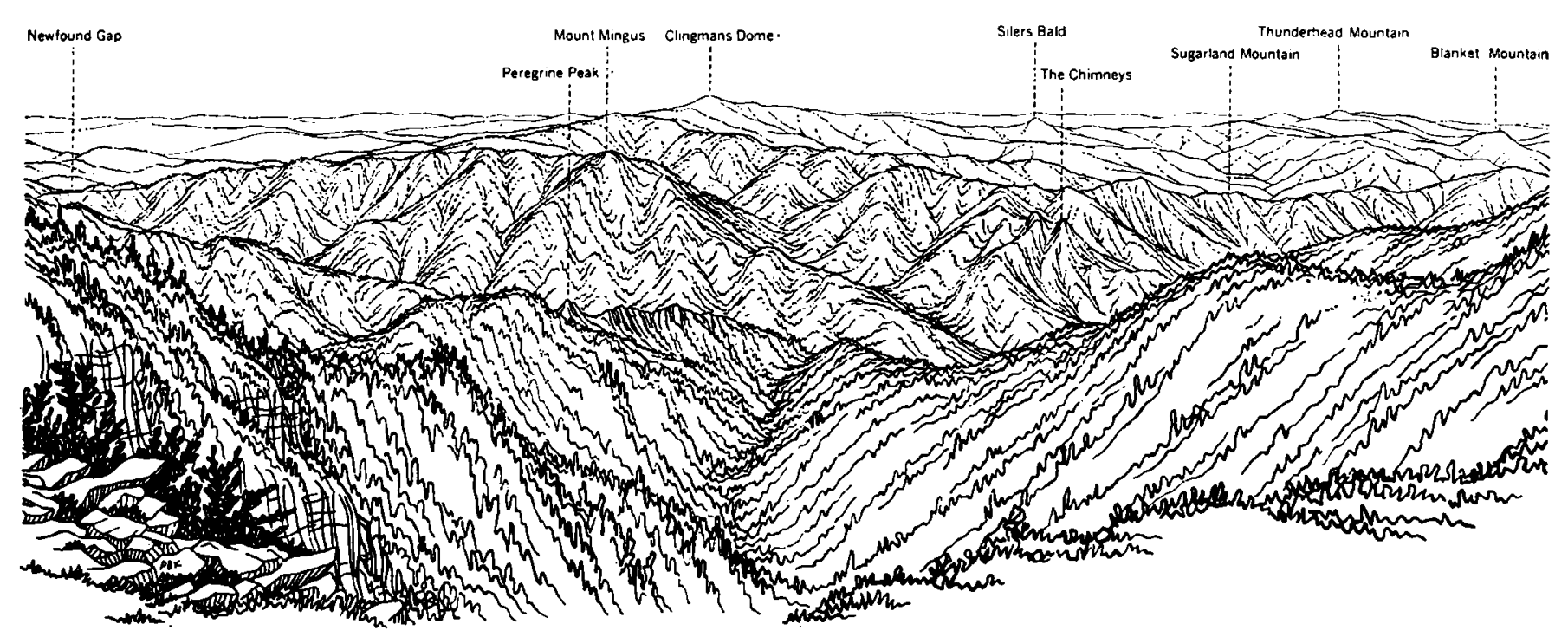

Figure 1. View from Cliff Top on Mount Le Conte, looking southwest across central part of the mountains. State-line divide is defined by Newfound Gap, Clingmans Dome, Silers Bald, and Thunderhead Mountain; valley of West Prong of Little Pigeon River in middle distance, that of main prong of Little River behind the ridge of Sugarland Mountain. The mountains in this view are all formed of the Great Smoky Group of the Ocoee Series. Note the steep-sided craggy pinnacles of Peregrine Peak surmounting Anakeesta Ridge, and The Chimneys, formed of the Anakeesta Formation; the contrasting smoother contours are characteristic of the Thunderhead Sandstone. Drawing by Philip B. King. 
The Great Smoky Group is well exposed along the transmountain highway (U.S. Highway 441) from 2 miles southeast of national park headquarters, across Newfound Gap, to Smokemont at the edge of the Cherokee Indian Reservation on the southeastern side. Along the north slope of the Great Smoky Mountains, as shown along the highway, the Great Smoky Group is tilted southeastward at moderate angles, forming a great homocline, which displays in places a thickness of as much as 25,000 feet of strata; elsewhere, especially toward the southeast, its rocks are tightly folded.

Along the north edge of the mountains the Great Smoky Group lies on the Snowbird Group, but the contact is a surface of movement called the Greenbrier fault, along which the higher unit has moved over the lower for a great but undertermined distance (pl. 1, structure section $\left.B-B^{\prime}\right)$. Farther south in the southeastern part of the mountains the Great Smoky Group rests conformably on the Snowbird Group. Nowhere in the Great Smoky Mountains is the top of the Great Smoky Group preserved, but south of the western part of the mountains the group is overlain by slate, quartzite, and marble of the Murphy marble belt (for example, in the Nantahala Gorge, south of the area mapped) (Keith, 1907, p. 4-5; Hurst, 1955, p. 45-56). These overlying formations are downfolded into the Great Smoky Group; although the rocks are probably of early Paleozoic age like the older rocks of the Appalachian Valley on the northwest, no fossils have been found.

The Great Smoky Group is a thick monotonous mass of clastic sedimentary rocks, pebble conglomerate, coarse to fine sandstone, and silty or argillaceous rocks, which can be divided into three intertonguing formations-the relatively fine-grained Elkmont Sandstone below, the coarse-grained Thunderhead Sandstone in the middle, and the dark silty and argillaceous rocks of the Anakeesta Formation above. This subdivision is most evident on the north slope of the mountains, as along the transmountain highway and on the slopes of Mount Le Conte (cover drawing). The three formations are less apparent farther east and southeast, where nearly all the Great Smoky Group has the character of the Thunderhead Sandstone, as shown on the map (pl. 1), but where it undoubtedly includes thick bodies of strata higher than any on the north side, including strata at or above the level of the Anakeesta Formation.

Both the Elkmont and Thunderhead Sandstones are somber gray and thick bedded and are composed principally of quartz and potassic feldspar grains, with lesser quantities of plagioclase feldspar and here and there a few pebbles of light-colored granite and quartzite. In the Thunderhead Sandstone many of the quartz grains are conspicuously blue tinted, but such grains are less abundant in the Elkmont Sandstone beneath. Characteristically, the sandstone beds of both formations are graded; that is, the basal part of each layer is coarser than the top part, which is commonly separated from the next sandstone layer by a parting of silty or argillaceous material. The graded layers are a few feet to 25 feet thick, but in each layer the whole textural range of each formation is displayed, from coarse to fine, repeated through thousands of feet of sequence. In the Thunderhead Sandstone the coarse bottom parts of the layers contain pebbles an eighth of an inch to more than half an inch in diameter; in the Elkmont Sandstone, however, the coarsest grains are rarely larger than sand size.

The Anakeesta Formation consists mainly of dark silty and argillaceous rocks altered to slate, phyllite, or schist. It forms steep-sided ridges and craggy pinnacles in the higher parts of the Great Smoky Mountains--such as The Chimneys, the prominent landmark that overlooks the transmountain highway from the west. The silty and argillaceous rocks contain a little free carbon and iron sulfides which produce dark and rusty weathered surfaces. Although the dark fine-grained rocks are the most common components of the Anakeesta Formation, sandstone layers like those of the Thunderhead Sandstone are commonly interbedded with them, and the two formations intertongue extensively. Thus, in places, sandstone replaces the dark fine-grained rocks, and the Anakeesta ceases to be identifiable. The Anakeesta Formation is therefore shown on the geologic map as discontinuous strips and patches; some of these have been isolated from the rest of the formation by faulting or folding, but most of them represent tongues or lenses in a dominant body of sandstone.

\section{Unclassified formations of Ocoee Series}

Associated with the Snowbird Group in the foothills north of the Great Smoky Mountains are several areas of coarser sandy rocks. They have some features like those of the Snowbird Group but many more features like those of the Great Smoky Group, although there are some subtle differences, such as absence of blue-tinted quartz grains. Seemingly, they are transitional vertically, and to some extent laterally, from one group to the other, and therefore are not included in any of the groups of the Ocoee Series. 
Such unclassified rocks occur on the lower slopes of the northeast end of the Great Smoky Mountains near Mount Cammerer, as well as on Webb Mountain and Big Ridge in the foothills several miles to the northwest and in the hills north and west of Cades Cove much farther west. Those on Mount Cammerer are termed the Rich Butt Sandstone; those on Webb Mountain and Big Ridge are unnamed but are probably equivalent to the Rich Butt (Hamilton, 1961, p. A15); those near Cades Cove are termed the Cades Sandstone. Rocks of similar character occur on the high foothill ridge of Cove Mountain northwest of Gatlinburg, but as these have somewhat more resemblance to the Great Smoky Group of the mountains and physically adjoin it, they are mapped as Elkmont Sandstone and Thunderhead Sandstone. Although these unclassified rocks are exposed in relatively small areas, thicknesses as great as 3,000-4,000 feet are preserved in nearly all their exposures.

The Rich Butt Sandstone and the rocks of Webb Mountain and Big Ridge lie conformably on the Pigeon Siltstone, and there is some evidence that the lower beds of the Rich Butt intertongue laterally with the Pigeon. Relations of the Cades Sandstone to the adjoining Metcalf Phyllite are less obvious because these two units occur in a region of much greater faulting and shearing. The Rich Butt Sandstone is mainly light-colored feldspathic sandstone in thin to thick beds, with sharply contrasting thin argillaceous interbeds, and some laminated silty or argillaceous units much like parts of the Pigeon Siltstone. Some coarse thick-bedded sandstone with graded bedding occurs in places in the Rich Butt, but it dominates the upper two-thirds of the sequence on Webb Mountain and Big Ridge and forms most of the sequence near Cades Cove. The tops of all these sequences are faulted off; the Rich Butt Sandstone is separated from the overlying Great Smoky Group by the Greenbrier fault; the rocks of Webb Mountain, of Big Ridge, and near Cades Cove have been thrust northward on other faults over various formations of the Ocoee Series.

\section{Walden Creek Group}

The northern and northwestern parts of the foothills are formed by another assemblage of sedimentary rocks, which are considerably more varied than the remainder of the Ocoee Series and are termed the Walden Creek Group. This group is mostly shale and siltstone, but it includes discontinuous masses of conglomerate and sandstone, as well as minor layers of quartzite, limestone, and dolomite. Especially distinctive are the conglomerates, which are formed mostly of large rounded white quartz pebbles, with minor amounts of pebbles of black quartzite, granite, limestone, and a variety of other rocks. Many of the characteristic rocks and structures of the Walden Creek Group can be observed along Tennessee Highway 73 in its course along the Little River between Chilhowee Mountain and Tuckaleechee Cove, and along U.S. Highway 129 along the Little Tennessee River (Neuman and Nelson, 1965, p. D15, D57).

Structural disorder in the Walden Creek Group exceeds that in any other group of the Ocoee Series, partly because of the weakness of its dominant shales and siltstones during deformation, partly because the group is underlain at shallow depth by the major low-angle Great Smoky thrust fault (pl. 1, structure sections $C-C^{\prime}$ and $D-D^{\prime}$ ). Its conglomerates and other strong rocks are thus broken into discontinuous lenses, and its silty and argillaceous rocks are intensely folded and crumpled nearly everywhere.

Broad differences in rock types are apparent from one part of the Walden Creek Group to another, but their original sequence and distribution are difficult to ascertain. Relations are clearest in the eastern part of the foothills south of English Mountain and near the main middle prong of the Little Pigeon River, where the group has been divided in ascending order into the Licklog, Shields, Wilhite, and Sandsuck Formations (Hamilton, 1961, p. A18). No continuous sequence of these formations can be found, but they probably have an aggregate thickness of about 8,000 feet. Rocks similar to these formations occur farther west in the outcrop belt of the Walden Creek Group (King, 1964, p. C45; Neuman and Nelson, 1965), and the same classification is used there.

Within the foothills north of the Great Smoky Mountains, the base of the Walden Creek Group is not visible; it is underlain by the Great Smoky fault along which it has been thrust over Paleozoic rocks, and it is downfaulted against the Snowbird Group on the south. Northeast of the map area, however, near the French Broad River, the Walden Creek Group conformably succeeds the Snowbird Group (Oriel, 1950, p. 23-24; Ferguson and Jewell, 1951, p. 16-17).

The Licklog Formation, the basal unit of the Walden Creek Group, now lies on the Great Smoky fault but perhaps was originally deposited on the Snowbird Group. It is dominantly a fine-grained sedimentary rock-shale and sandstone-but it is overlain by the Shields Formation which contains great masses of coarse conglomerate of the type characteristic of the group as a whole; this conglomerate in intermingled with coarse sandstone and 
intertongues with shale. The Shields is followed by the Wilhite Formation, dominantly a siltstone much like the Pigeon, but containing many lenses of conglomerate like that in the Shields, as well as some lenses of pure white quartzite, and in the upper part, many lenses and beds of limestone and dolomite. The Sandsuck Formation is again dominantly shaly, although, like the other formations, it contains many conglomerate lenses.

South of English Mountain the top of the Sandsuck Formation is not preserved, but in the lengthy fault block of Chilhowee Mountain farther west the Sandsuck is overlain by the Cochran Formation of Early Cambrian(?) age-the basal unit of the Chilhowee Group. In the northeastern part of Chilhowee Mountain the Cochran seemingly lies disconformably on the Sandsuck, that is, upon its eroded and somewhat truncated surface (King, 1964, p. C57-C59); farther southwest, the two may be conformable (Neuman and Nelson, 1965). In any event, the two formations are markedly different-the Sandsuck with contrasting coarse and fine very irregular layers that formed in an unstable environment, the Cochran with less contrasting very persistent layers that formed in a stable environment.

\section{Interpretation of Ocoee Series}

All the sediments of the Ocoee Series were deposited under water, very probably in a single large marine basin. Its component groups, however, were obviously formed in different environments. In some places the different deposits of these groups are superposed in stratigraphic sequences, but for the most part they are now preserved in separate fault blocks, juxtaposed by thrusting of undetermined magnitude. The rocks of these fault blocks are mere fragments of the original deposit, the connections between which are now lost. Thus, a definitive reconstruction cannot yet be made of either the original relations of the groups or their history. Nevertheless, some speculations can be offered.

Pertinent to such speculation are the following:

1. The Snowbird Group lies unconformably on the basement complex, and is the oldest unit of the Ocoee Series.

2. In most of the southeastern part of the mountains the Snowbird Group is thin and is overlain conformably by the Great Smoky Group.

3. In places in this part of the mountains the Snowbird Group wedges out, so that the Great Smoky Group is the basal deposit.
4. Farther northwest the Snowbird Group is thick and is overlain conformably by unclassified formations of the Ocoee Series, which may be a vertical and lateral transition from the Great Smoky to the Snowbird Group.

5. In the foothills northwest of the Great Smoky Mountains the Walden Creek Group adjoins the Snowbird Group along a faulted contact, but probably originally overlay it.

6. The Walden Creek Group is overlain on the northwest by the Chilhowee Group, at least part of which is of early Paleozoic age.

7. The Great Smoky Group is overlain on the south by formations of the Murphy marble belt, which are likewise probably of early Paleozoic age.

These facts still leave many questions of interpretation unanswered, for it is clear that the three groups of the Ocoee Series do not form a single stratigraphic sequence. Although they are not themselves in contact, both the Great Smoky Group and the Walden Creek Group overlie the Snowbird Group in different places. What, therefore, is the relation of the great mass of coarse sediments of the Great Smoky Group to the thinner and very different sediments of the Walden Creek Group to the northwest?

Much of the thinning of the Snowbird Group from the northeastern to the southeastern part of the mountains presumably results from overlap of the Snowbird Group against the basement complex, as shown by the increase in amount of the coarse sandy deposits of the Longarm Quartzite in this direction. However, at least some of it is caused by intertonguing of the Snowbird with such coarser formations as the Rich Butt Sandstone, which in turn probably pass southeastward into the Great Smoky Group. The relation of the Great Smoky Group to the Walden Creek Group farther northwest is less clear, because the two are not only very different, but they are separated by a belt several miles wide, which was probably much wider before folding and thrusting. Nevertheless, because both groups overlie the Snowbird, and because both are overlain by strata of early Paleozoic, or probable early Paleozoic age, they are probably laterally equivalent.

The Snowbird Group is a basal and marginal deposit, laid down against a rough surface of the basement complex that projected into the northeastern part of the depositional basin, and from which the coarse sandstones of the group were derived. Its coarser grained rocks give place southwestward along the outcrop to finer grained rocks, and still farther southwest the finer grained rocks may become indistinguishable from similar rocks of the 
Walden Creek Group. The Walden Creek Group was probably laid down on an unstable shelf that fringed the continental interior toward the northwest. Some of its deposits were laid down in shallow water; others slumped from shallow water into somewhat deeper water at the edge of the shelf. The Great Smoky Group accumulated farther southeast, away from the continent, probably in water of much greater depth than did the other two groups, perhaps in a submarine trench of tectonic origin. Its ubiquitous graded bedding indicates that most of the sediments that accumulated in the trench were transported there by turbidity currents. The source of these sediments cannot be identified, but they decrease in grain size southwestward from Tennessee to Georgia, suggesting that the trough was filled from its northeastern end and that the sediments were derived from the basement rocks well to the northeast. The northwestern edge of the trench must have been the unstable shelf on which the Walden Creek sediments were accumulating. Its southeastern edge is undefined, as it is adjoined in this direction by older rocks of the basement complex, which are in turn adjoined by the highly metamorphosed rocks of the Piedmont province, whose age and sequence are as yet uncertain. It might be that the southeastern edge of the trench in which the Great Smoky sediments accumulated included the site of the northwestern part of the Piedmont province, where its deposits are now greatly metamorphosed and unrecognized.

The time during which the Ocoee sediments accumulated was later than the creation of the basement complex in earlier Precambrian time, and before the deposition of the oldest Paleozoic sediments, hence probably in late Precambrian time. Much searching has failed to reveal any fossil remains in the Ocoee Series. This might suggest that they are of pre-Paleozoic age were it not that large parts of the Ocoee sediments are of types that would be poorly fossiliferous whatever their age. More significant is the fact that the lowest fossil remains in the sequence on Chilhowee Mountain are of Early Cambrian age, and that these fossils occur well above the top of the Walden Creek Group and the Ocoee Series.

\section{Paleozoic Rocks}

The third chapter of this account of the bedrock geology of the Great Smoky Mountains and their surroundings, that of the Paleozoic rocks and of Paleozoic time, can be treated more briefly than the preceding two chapters. Most of the Paleozoic rocks involved are northwest of the Great Smoky Mountains and the Great Smoky
Mountains National Park, and they have been described at length in other publications (Rodgers, 1953, p. 42 110; Neuman, 1955, p. 146-165; Cattermole, 1955; Neuman, 1960; Neuman and Wilson, 1960; Cattermole, 1962).

The Paleozoic formations northwest of the Great Smoky Mountains are shown on the accompanying geologic map (pl. 1) and are summarized in table 2.

The Paleozoic rocks occur in three different structural and geographic situations. The first is in the Great Smoky and related thrust sheets, where they form Chilhowee Mountain and Miller Cove on the west edge of the foothill belt (pl. 1, structure sections $C-C^{\prime}$ and $D-D^{\prime}$ ) and English and Green Mountains on the east (pl. 1, structure section $A-A^{\prime}$ ); here, only the lower part of the Paleozoic sequence is preserved. The second is beneath the Great Smoky fault and northwest of its leading edge in the Appalachian Valley; here, all the formations of the upper part of the Paleozoic sequence are preserved, from the Cambrian Rome Formation, through the Ordovician and Devonian, to the Mississippian Greasy Cove Formation. The third is beneath the Great Smoky fault in Wear, Tuckaleechee and Cades Coves, and at Calderwood where the Paleozoic rocks have been revealed in windows produced by erosion through the Great Smoky thrust sheet; here, a small part of the more complete sequence of the Appalachian Valley emerges-limestone of the Ordovician part of the Knox Group and shales, sandstones, and limestones of the lower part of the Middle Ordovician Series.

The Paleozoic rocks of the first category form long knife-edged ridges, such as Chilhowee Mountain, lined with quartzite ledges of the Chilhowee Group on its northwest face (fig. 2), and with dip slopes on the southeast that pass beneath the Shady and Rome Formations in the low ground of Miller Cove. The Paleozoic rocks of the second category form the low country of the Appalachian Valley, cleared, farmed, and well populated; the limestones of the valley form fertile, rolling country, and the shales form low, knobby hills. The Paleozoic rocks of the third category form low, cleared, fertile coves that duplicate the Appalachian Valley in miniature, surrounded by the dark, forested foothills of the Great Smoky Mountains.

The Chilhowee Group at the base of the Paleozoic sequence is of special interest, for it contains the oldest fossil remains in the Great Smoky Mountain region. The Helenmode Formation at the top has been known for many years to contain fragments of the trilobite Olenellus 
TABLE 2.-Paleozoic formations in the vicinity of the Great Smoky Mountains

\begin{tabular}{|c|c|c|c|c|}
\hline System & Series & $\begin{array}{l}\text { Formation } \\
\text { or group }\end{array}$ & $\begin{array}{l}\text { Thickness } \\
\text { (feet) }\end{array}$ & Description \\
\hline \multirow{2}{*}{ Mississippian } & Upper & $\begin{array}{l}\text { Greasy Cove } \\
\text { Formation }\end{array}$ & 400 & Limestone, shale, and sandstone. \\
\hline & Lower & $\begin{array}{c}\text { Grainger } \\
\text { Formation }\end{array}$ & 1,000 & Siltstone, sandstone, and conglomerate. \\
\hline Devonian & Upper & Chattanooga Shale & 25 & $\begin{array}{l}\text { Thin persistent unit of black carbonaceous } \\
\text { shale. }\end{array}$ \\
\hline \multirow{7}{*}{ Ordovician } & \multirow{6}{*}{ Middle } & Bays Formation & 900 & $\begin{array}{l}\text { Red calcareous mudrock and siltstone; white } \\
\text { sandstone at the top. }\end{array}$ \\
\hline & & Sevier Formation & 2,000 & $\begin{array}{l}\text { Greenish-gray calcareous shale, sandstone, } \\
\text { and calcarenite. }\end{array}$ \\
\hline & & Chota Formation & $700-1,000$ & Dark-red to reddish-gray quartzose calcarenite. \\
\hline & & Tellico Formation & 3,400 & $\begin{array}{l}\text { Greenish gray calcareous shale; persistent } \\
\text { calcareous sandstone units. }\end{array}$ \\
\hline & & Blockhouse Shale & 400 & $\begin{array}{l}\text { Dark-gray calcareous shale; nodular lime. } \\
\text { stone at base. }\end{array}$ \\
\hline & & Lenoir Limestone & 100 & $\begin{array}{l}\text { Dark-gray nodular and light-gray dense lime- } \\
\text { stone; basal conglomerate in places. }\end{array}$ \\
\hline & Lower & \multirow{2}{*}{ Knox Group } & \multirow[b]{2}{*}{3,100} & \multirow{2}{*}{$\begin{array}{l}\text { Gray thick-bedded limestone and dolomite, } \\
\text { very cherty in part; divisible into five for- } \\
\text { mations of dolomite and minor limestone } \\
\text { in Appalachian Valley; dominantly lime- } \\
\text { stone in cove areas of Great Smoky } \\
\text { Mountains foothills. }\end{array}$} \\
\hline \multirow{7}{*}{ Cambrian } & \multirow[t]{2}{*}{ Upper } & & & \\
\hline & & Conasauga Group & 1,500 & $\begin{array}{l}\text { Gray, calcareous shale; several limestone } \\
\text { formations. }\end{array}$ \\
\hline & \multirow{5}{*}{ Lower } & Rome Formation & 1,000 & $\begin{array}{l}\text { Mostly red shale adjacent to mountains; } \\
\text { includes much siltstone, sandstone and } \\
\text { dolomite to the northwest. }\end{array}$ \\
\hline & & Shady Dolomite & 1,200 & Gray to dark-gray thick-bedded dolomite. \\
\hline & & $\begin{array}{l}\text { Helenmode } \\
\text { Formation }\end{array}$ & 200 & $\begin{array}{l}\text { Glauconitic siltstone and sandstone, calcare } \\
\text { ous in part. }\end{array}$ \\
\hline & & $\begin{array}{c}\text { Hesse } \\
\text { Quartzite }\end{array}$ & 500 & White thick-bedded vitręous quartzite. \\
\hline & & Murray Shale & 350 & $\begin{array}{l}\text { Greenish-gray micaceous glauconitic non- } \\
\text { calcareous siltstone and fine-grained } \\
\text { sandstone. }\end{array}$ \\
\hline \multirow{3}{*}{ Cambrian(?) } & \multirow{3}{*}{$\begin{array}{c}\text { Lower } \\
(?)\end{array}$} & Nebo Quartite & 400 & $\begin{array}{l}\text { White thin- to medium -bedded vitreous } \\
\text { quartzite. }\end{array}$ \\
\hline & & Nichols Shale & 600 & $\begin{array}{l}\text { Greenish.gray micaceous glauconitic non- } \\
\text { calcareous siltstone; thin beds of sand. } \\
\text { stone and quartzite. }\end{array}$ \\
\hline & & $\begin{array}{l}\text { Cochran } \\
\text { Formation }\end{array}$ & 1,200 & $\begin{array}{l}\text { Thick-bedded quartzite and arkosic sand. } \\
\text { stone, finely conglomeratic in lower part; } \\
\text { red silty shale near base in places. }\end{array}$ \\
\hline Precambrian & Ocoee & \multicolumn{3}{|c|}{ Sandsuck Formation of Walden Creek Group } \\
\hline
\end{tabular}

and other fossil shells, which were collected at Walland at the south end of the gap of the Little River through Chilhowee Mountain (Walcott, 1890, p. 570; Resser, 1938, p. 25). Recently, other fossil shells have been obtained from the Murray Shale lower down in the sequence, from cuts on the Foothills Parkway near Look Rock southwest of Walland; these are shells of the primitive ostracode Indiana (Laurence and Palmer, 1963). Beside these fossil shells, all the formations of the Chilhowee Group above the Cochran contain traces of former life; the quartzites and sandstones contain closely spaced vertical tubes called Scolithus, probably the burrows of a primitive sea worm; the shales and siltstones show various tracks and trails on the bedding surfaces. Because of the occurrence of definite fossil shells in the Murray Shale, this and the higher formations of the Chilhowee Group are classified unequivocally as Lower Cambrian. The underlying formations of the Chilhowee Group are also very likely to be Cambrian, because some of them contain traces of highly organized animal life, and because their rocks are much like, or even identical with, the fossiliferous rocks conformably above them. However, as true fossil shells that would establish an age have so far not been collected from these formations, their assignment to the Lower Cambrian remains questionable.

The succeeding Cambrian and Lower Ordovician formations, from the Shady Dolomite to the top of the Knox Group, are a great sequence of carbonate rocks nearly 7,000 feet thick-mainly limestone and dolomite, with some shaly units like the Rome Formation and the Conasauga Group that are themselves also limy. These indicate a long epoch of quiet deposition in the marine waters of the Paleozoic Appalachian geosyncline-a time when the region was far from any shore, and when even the distant lands in the interior of the continent to the northwest were too low to contribute much erosional debris.

The succeeding Middle Ordovician strata are a sequence of clastic rocks as thick as or thicker than the carbonate sequence-shales and sandstones with little true limestone, ending with red mudrock at the top. These deposits indicate a notable change in the environment of the Appalachian geosyncline, a rising of lands near enough to it and high enough to contribute large quantities of erosional debris (Neuman, 1955, p. 171). These lands must have been southeast of the Middle Ordovician rocks now exposed, for the quantity of shaly and sandy material in the series increases in successive outcrops 


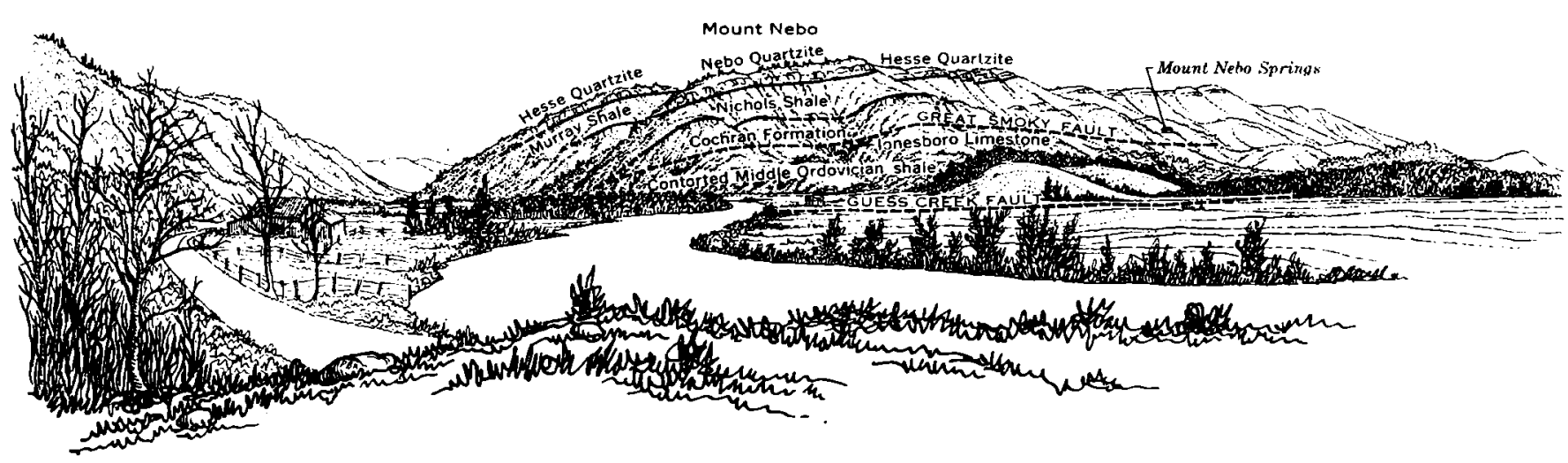

FIGURE 2.-Little River gap looking southeast from crest of ridge supported by Chota Formation. The subdivision of the Chilhowee Group on Ghilhowee Mountain are delineated, together with the traces of the Great Smoky and Guess Creek faults. The gap itself follows a minor transcurrent fault, so that the continuity of the formations on its opposite sides is broken. Tennessee Highway 73 is across the river from this viewpoint. Drawing by Philip B. King.

southeastward across the Appalachian Valley, and the amount of limy material decreases. This would imply that the lands of Middle Ordovician time were in the direction of the present Great Smoky Mountains, although whether they were on the site of the present mountains or somewhere farther away is unkown. The creation of these lands is significant in the interpretation of the history of the Great Smoky Mountain region, as it indicates crustal unrest in the vicinity, thus supporting an inference that some of the structures in the Great Smoky Mountains formed during early or middle Paleozoic time (see below under "Structure of the bedrock").

The highest rocks of the Paleozoic sequence northwest of the Great Smoky Mountains are of Late Mississippian age and are likewise significant in dating the structural history of the mountain region. These Mississippian rocks are preserved in a narrow syncline along the northwestern slope of Chilhowee Mountain which is caught under the leading edge of the Great Smoky thrust sheet (pl. 1, structure section $D-D^{\prime}$ ) (Neuman and Wilson, 1960; Neuman and Nelson, 1965, p. D54). The Mississippian rocks are not actually in contact with the Great Smoky fault, as they are separated from it by a narrow fault slice of Middle Ordovician rocks. Nevertheless, their close association with the fault indicates that the emplacement of the Great Smoky thrust sheet in its present position occurred after the end of Mississippian time, probably during some later part of the Paleozoic era.

\section{Igneous Rocks}

Except for the granitic rocks of the basement complex, the Great Smoky Mountains and vicinity are conspicu- ously a region of sedimentary rocks and their metamorphosed equivalents. Few igneous rocks occur, and most of these form bodies too small and too inconspicuous to be shown on the map (Hadley and Goldsmith, 1963, p. B69-B74). The only igneous rock mapped is metadiorite, a rock composed mainly of hornblende and plagioclase. It forms some narrow sills parallel to beds in the Thunderhead Sandstone near the mountain crest between Newfound Gap and Clingmans Dome. These sills extend at least 15 miles southwestward across the unmapped area on the south slope of the mountains, where they have been observed near the old copper mines along Hazel Creek (Espenshade, 1963, p. I19). The sills are believed to have been introduced after the initial metamorphism of the rocks of the Ocoee Series and before the final metamorphism, hence during some part of Paleozoic time.

\section{Structure of the Bedrock}

The bedrock formations of the Great Smoky Mountains and vicinity have been greatly folded and faulted, and those in the mountains themselves and farther southeast have been variably metamorphosed as well. The structures thus produced are illustrated on the four structure sections that accompany the map (pl. 1). Detailed descriptions and interpretations of these structures have been given elsewhere (Hamilton, 1961, p. A35-A46; Hadley and Goldsmith, 1963, p. B74-B96; King, 1964, p. C87-C130; Neuman and Nelson, 1965, p. D45-D68). Here, only the principal faults of the region will be discussed, the bearing which they have on the distribution of the bedrock formations, and their implications in the geologic history. 
Three major faults occur, each with a different character and age, and each accompanied by minor related faults:

1. The Greenbrier fault, together with its related faults, occurs within the Ocoee Series of the mountain area, is older than the other two major faults, and is perhaps of earlier Paleozoic age.

2. The Great Smoky fault, however, with its related faults occurs between the Ocoee Series and the Paleozoic rocks at the border between the foothills and the Appalachian Valley, and is of later Paleozoic age.

3. The Gatlinburg fault, together with its related faults, occurs within the Ocoee Series near the northwest foot of the Great Smoky Mountains, is as young as or younger than the Great Smoky and related faults, but is probably also of later Paleozoic age.

\section{Greenbrier and Related Faults}

The Greenbrier fault is prominently displayed in the eastern half of the Great Smoky Mountains (Hadley and Goldsmith, 1963, p. B74-B81). It also extends westward nearly the length of the mountains, but in the western half it is much broken up by younger faults and is not continuously exposed (King, 1964, p. C106-C113).

The Greenbrier fault is a low-angle thrust which lies along the contact between the Great Smoky Group and the underlying Snowbird Group. As this relation was their original stratigraphic arrangement, movement on the Greenbrier fault has carried younger rocks over older through the greater part of its length. The actual surface of the fault is exposed in few places, but its existence is indicated by contrasting structures in the rocks above and below it, and by truncation of these structures at the fault, as shown on the geologic map (pl. 1). It is further suggested at the east end of the mountains by close juxtaposition of the thick sequence of Snowbird Group below the fault and the very thin sequence of Snowbird Group above the fault; reconstruction of the original positions of the thin and thick sequences suggests that they once lay at least 15 miles apart and that the rocks above the fault have moved this distance or even farther (Hadley and Goldsmith, 1963, p. B80).

Between the east end of the mountains and the Pigeon River, the fault is warped around the large Cataloochee anticlinorium. On the southeastern flank of the anticlinorium, the basement complex emerges along the upper side of the fault, so that the fault descends into the base- ment in this direction. Farther west in the mountains, mainly in the Cherokee Indian Reservation, the fault comes to the surface in the Ravensford anticline, and a large area of the rocks beneath is revealed (pl. 1, structure section $\left.B-B^{\prime}\right)$. Here, as in the Cataloochee anticlinorium, the basement complex is involved. In most of the anticline, only basement complex is exposed beneath the fault, but along Straight Fork at its northeastern end, rocks of the Snowbird Group emerge in a window from beneath the basement. These rocks have been overridden by the basement along another low-angle fault, which is akin to the Greenbrier fault and lies a little beneath it (Hadley and Goldsmith, 1963, p. B85-B88).

Other faults related to the Greenbrier fault occur elsewhere in the mountains, mostly forming the soles of various small slices of formations of the Ocoee Series that lie directly beneath the main fault. Some faults that lie farther north in the foothill area are older than structures adjacent to them and may have formed at the same time as the Greenbrief faulting-for example, the faults beneath the unclassified formations of the Ocoee Series on Webb Mountain, Big Ridge, and near Cades Cove and the Dunn Creek fault which separates the Snowbird Group from the Walden Creek Group in the eastern part of the foothill belt (Hamilton, 1961, p. A40-A42).

The Greenbrier and its related faults evidently formed early in the deformational history of the Great Smoky Mountain region. The Greenbrier fault, for example, was subsequently folded near the Cataloochee anticlinorium and the Straight Fork window, and it was disrupted by the Gatlinburg and related faults that cross it in the western part of the mountains. It is also older than much of the regional metamorphism, for near the Cataloochee anticlinorium the rocks both above and below it pass southward from a low-grade metamorphic facies characterized by biotite into higher grade facies characterized by garnet and staurolite (Hadley and Goldsmith, 1963, p. B106). Near Gove Mountain northwest of Galinburg the rocks below and above the fault lie in a still lower grade facies characterized by chlorite. Evidently, these metamorphic facies were imposed on the rocks after the fault and its thrust sheet had been emplaced in their present positions.

\section{Great Smoky and Related Faults}

The Great Smoky fault lies at the northern edge of the foothills of the Great Smoky Mountains, on the border of the Appalachian Valley (Neuman, 1951, p. 743-750). 
Unlike the Greenbrier fault, which is known only in the region of the Great Smoky Mountains, the Great Smoky and its related faults are one segment of a very extensive system of displacement that extends for hundreds of miles along the southeastern edge of the Appalachian Valley-from central Virginia to Alabama (Rodgers, 1953, p. 139-147).

Like the Greenbrier fault, the Great Smoky fault is a low-angle thrust, but, unlike the Greenbrier fault, the Great Smoky fault everywhere carries older rocks over younger. Near the Great Smoky Mountains it mostly carries rocks of the Ocoee Series over Ordovician and younger Paleozoic rocks, although near its leading edge, earlier Paleozoic rocks, mainly Chilhowee Group, form part of the thrust sheet. The surface of the fault is exposed in many places, in stream channels and various artificial excavations. It is seen to be mostly a smooth clean-cut surface with little accompanying fault gouge or breccia, which dips at various but generally low angles.

The low dip of the Great Smoky fault applies also to its larger relations, so that it lies at shallow depth for many miles southeast of its leading edge. From this leading edge the fault dips southeastward beneath Chilhowee Mountain, but it rises again in the foothills beyond where it has been exposed by erosion in several places (pl. 1, structure sections $C-C^{\prime}$ and $D-D^{\prime}$ ) (King, 1964, p. C92-C96; Neuman and Nelson, 1965, p. D45-D56). It thus emerges again around the edges of Wear, Tuckaleechee, and Cades Coves (fig. 3), which are floored by Ordo- vician rocks that lie beneath the fault. The coves are therefore windows in the thrust sheet of Ocoee Series that overlies the fault. A smaller window of the same kind occurs farther southwest, at Calderwood on the Little Tennessee River, and another one to the northeast, on the Cades Cove road east of Crib Gap. The latter is not well exposed, but its existence is indicated by sinkholes in the valley gravels and by a drill hole that penetrated limestone beneath the gravels.

These windows lie well behind the leading edge of the Great Smoky fault and demonstrate that extensive movement has occurred along it. The window east of Crib Gap lies farthest southeast of the leading edge, a distance of 9 miles. The Ocoee Series of the thrust sheet above the fault has moved at least this far northwestward over the Ordovician and other Paleozoic rocks, and very likely much farther.

Many lesser faults are associated with the Great Smoky fault, most of which are branches that displace the rocks in the northwestern part of the main thrust sheet; some of these have very large displacements of their own. One of them, the Miller Cove fault, borders the southeastern side of the Chilhowee Mountain block for its entire length, generally separating the Chilhowee Group and younger Cambrian strata of the fault block from the Walden Creek Group of the Ocoee Series on the southeast. It mostly forms a single break, but it splits into branches northeastward (King, 1964, p. C98-C100). Similar branch faults occur still farther east, bordering the north

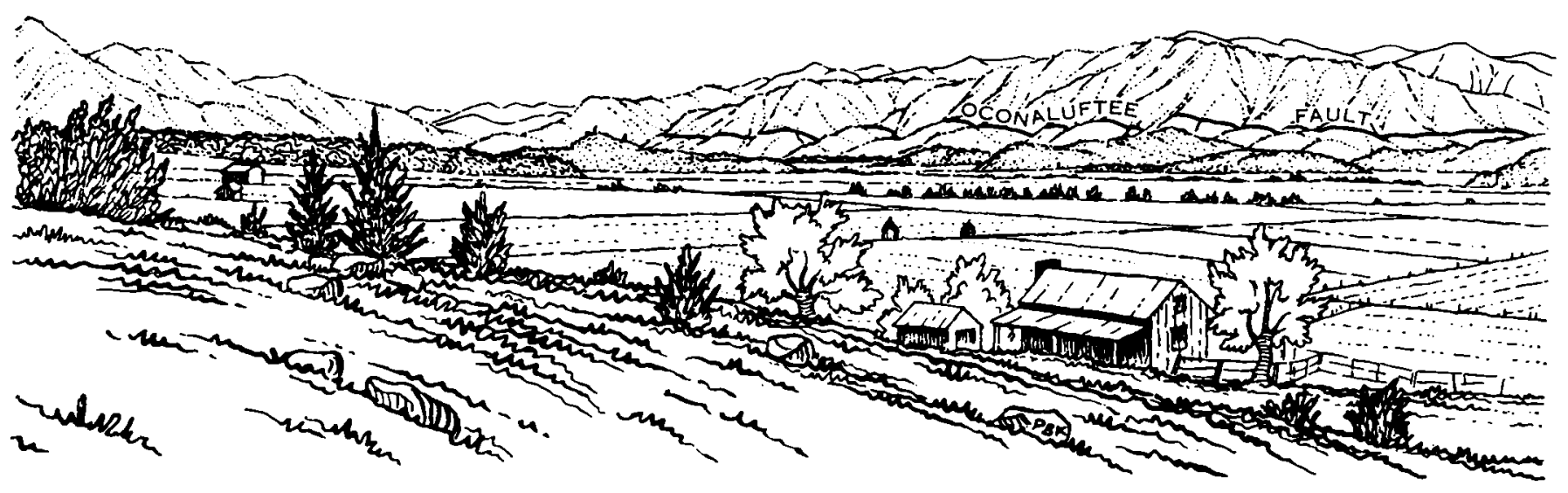

Frgure 3.-View of Cades Cove, looking east-southeast. The trace of the Great Smoky fault lies between the viewer and the house (now dismantled) in the foreground, and elsewhere largely rims the cove floor. The trace of the Oconaluftee fault lies approximately at the break in slope between the spurs and the main ascent of the mountains that form the backdrop of the cove in the central and right-hand parts of the view. The rocks above the Oconaluftee fault belong to the Elkmont Sandstone of the Great Smoky Group; those between the Oconaluftee and Great Smoky faults belong to the Metcalf Phyllite of the Snowbird Group. The rocks of the cove floor beneath the Great Smoky fault are limestones of the Knox Group of Ordovician age. Drawing by Philip B. King. 
and south sides of English Mountain, and these extend beyond the Pigeon River (Hamilton, 1961, p. A43-A44).

Other faults related to the Great Smoky fault form the soles of slices of Paleozoic rocks, which were broken off from the block beneath and were dragged over the main body of Paleozoic rocks for various distances during emplacement of the thrust sheet. Such faults and slices occur at intervals along the leading edge of the Great Smoky fault, but are more conspicuous in the cove, or window, areas. Here are many slices a few feet to several hundred feet thick of Lower Ordovician limestone, and two or three slices of quartzite of the Chilhowee Group, most of which overlie Middle Ordovician shale of the main window areas.

The Great Smoky and related faults formed late in the deformational history of the Great Smoky Mountain region. The Mississippian rocks that lie close against the leading edge of the fault and that were involved in deformation during emplacement of its thrust sheet indicate that this emplacement must have occurred after Mississippian time. Also, unlike the Greenbrier fault, the Great Smoky fault formed after the Ocoee Series had been regionally metamorphosed. Close to the leading edge of the fault the Ocoee Series is little metamorphosed, but farther southeast, near the windows of Wear, Tuckaleechee, and Cades Coves and Calderwood, the rocks of the series contain chlorite, and near the window east of Crib Gap they contain biotite. These metamorphosed rocks lie on Ordovician limestones and shales exposed in the windows which, although deformed, contain none of these metamorphic minerals.

\section{Gatlinburg and Related Faults}

The Gatlinburg and related faults lie mostly near the foot of the main Great Smoky Mountains in the southern part of the foothill belt and entirely within the Ocoee Series (Hamilton, 1961, p. A45-A46; Hadley and Goldsmith, 1963, p. B75-B77; King, 1964, p. C113-C117). They extend from the east edge of the mapped area, past Gatlinburg, into the western part of the mapped area. Most of the faults trend east-northeast, with some branching and interlacing. One large fault, the Oconaluftee, branches off southeastward near the middle of the mountains, crosses the mountain crest at Indian Gap and extends down the valley of the Oconaluftee River on the southeastern slope. North of the Oconaluftee fault near Gatlinburg, the east-northeast-trending faults are crossed and partly offset by others trending north-northeast (King, 1964, p. C116). Nearby, another fault extends northwestward down the West Prong of the Little Pigeon River and may be responsible for a conspicuous offset in the trace of the Great Smoky fault near Pigeon Forge.

Unlike the other faults of the region, the Gatlinburg and related faults are well expressed in the topography. They commonly lie in stream valleys and cross from one stream valley to the next through notches in the intervening ridges. The result is a set of trenches or creases which extend nearly straight for long distances and are very evident on any relief model of the mountains. This topographic expression is the result of erosion along the fault lines probably because the rocks near them are much sliced and shattered, hence poorly resistant to erosion.

The straight traces of the Gatlinburg and related faults indicate that they dip at relatively steep angles-generally much steeper than either the Greenbrier or Great Smoky fault. The surface of the main east-northeast-trending Gatlinburg fault is exposed at a number of places and dips at an angle of $45^{\circ}$ or steeper to the south; older rocks on that side are raised against younger rocks on the north. Slickensides preserved at some of these exposures cross the fault surface at an angle to the dip, indicating that movement had both an updip (dip-slip) and a right lateral (strike-slip) component by which the older rocks on the south moved westward relative to the younger rocks on the north (Hadley and Goldsmith, 1963, p. B77). Strike-slip displacement must be even greater on the other large related fault the Oconaluftee, which in its northwest-trending segment laterally offsets steeply dipping rocks and structures on the two sides by as much as several miles. Westward this displacement was translated to dip-slip displacement on part of the older Greenbrier fault (Neuman and Nelson, 1965, p. D62-D63).

Although the Gatlinburg and related faults involve only rocks of the Ocoee Series, they must be a late feature of the deformation. They have broken and displaced the Greenbrier fault and its thrust sheet, and they extend indiscriminately through rocks that have been variably metamorphosed. A late age is also suggested by the marked topographic expression of the Gatlinburg and related faults; the fracturing and slicing of the rocks which has brought this about could not have been preserved if many structures had been superposed later. The Gatlinburg and related faults come into contact with the Great Smoky fault only near Pigeon Forge and at Cades Cove, but the mutual relations between these structures are obscure and their relative ages are unknown. However, the Gatlinburg and related faults seem to be at least as young as the Great Smoky fault and may be younger. 


\section{Folding}

Although the various types of faults previously described are the most influential features determining the present arrangement of the rocks of the area, these rocks were also strongly folded. Effects of this folding range from broad arches and long stretches of uniform dip, such as those seen in the thick-bedded sandstone of the Great Smoky Group on Mount Le Conte and elsewhere along the northern slope of the mountains, to small sharp folds in the shaly, less competent rocks of the Snowbird and Walden Creek Groups in the foothills to the northwest. Most folds in the northern part of the area trend eastnortheast and are asymmetric in that their northwarddipping beds are much steeper than the southward-dipping ones and are locally strongly overturned. Farther south where metamorphism is greater, abundant folds of several ages intersect and produce very complex relations as seen in individual exposures. Folding probably began at about the time of the Greenbrier thrusting but continued after the Great Smoky thrusting. In general it reflects relative upward and northwestward movements, in harmony with the major fault movements.

\section{Summary of Deformational History}

The earliest structures in the Great Smoky Mountain region are recorded in the basement complex. They formed in Precambrian time by deformation, metamorphism, and partial granitization of ancient stratified rocks, and were eroded and truncated before the Ocoee Series was laid down over them in later Precambrian time.

Deposition of the Ocoee Series seems to have been followed by the deposition of Paleozoic sediments without any conspicuous deformation. Along the northwestern edge of the Ocoee area, at least, the basal Cambrian and younger Paleozoic deposits overlie the top of the series with an inconspicuous erosional break at most, and, although the two assemblages of sediments differ much in origin, their structures and their degrees of metamorphism are nearly identical.

The first notable structures in the Great Smoky Mountain region that are younger than the earlier Precambrian are thus probably of Paleozoic and, perhaps, of early Paleozoic age; they may be related, at least tenuously, to the clastic deposits of Middle Ordovician age in the southeastern part of the Appalachian Valley. Conspicuous among the early structures are the Greenbrier and related faults, which have moved part of the Ocoee Series northwestward over another part for a distance of many miles.
At some later time in the Paleozoic, the Ocoee Series and its faulted structures were subjected to regional metamorphism. The rocks on the northwest were almost unaffected, but those on the southeast attained middle-grade metamorphism. During this time, the basement complex was remetamorphosed.

Late in Paleozoic time, at least later than Mississippian, the whole mass of the Ocoee Series, as well as its cover of earliest Paleozoic rocks, was thrust many miles northwestward across the main body of Paleozoic rocks along the Great Smoky fault. Paleozoic rocks overridden by the thrust are now exposed in the cove areas. During this thrusting, the rocks above the Greenbrier fault were carried along with the rest, thus moving them a still greater distance from their original site of deposition.

A very late event in the deformation of the region, as young as or younger than the Great Smoky thrusting and most of the folding, was the breakup of the Ocoee Series by the Gatlinburg and related faults, by some combination of dip-slip and strike-slip movements.

A final topic worthy of discussion is the growth of mountains on the site of the present Great Smoky Mountains. After Precambrian time the first indication of any mountainous lands near the present Great Smoky Mountains is afforded by the clastic rocks in the Middle Ordovician Series, which may be related to the earliest structures in the Great Smoky Mountains. Following these earliest structures, deformation continued, at least intermittently, until late in Paleozoic time-at least after Mississippian time. Continued deformation undoubtedly raised the whole Appalachian region, including the site of the Great Smoky Mountains, into a land area. We can guess that this land area was mountainous, but we cannot tell much about its surface features, because no contemporaneous sediments are preserved nearby.

From Paleozoic time to the present this land area has been continuously eroded, although the erosion may have been accelerated from time to time by renewed uplift without any accompanying deformation of the rocks. The modern Great Smoky Mountains are entirely a product of this prolonged erosion and uplift and are not themselves a direct product of the extensive deformation which is visible in the rocks that compose them.

\section{Noteworthy Exposures in the Area}

Several roadside parking areas in and near Great Smoky. Mountains National Park afford excellent opportunities to examine geologic features described in the fore- 
going pages. The best of these are described in the following notes. With the geologic map, the visitor will be able to identify the formations and structures exposed elsewhere.

The exposures described here are along the more heavily traveled highways: Tennessee Highway 73 from the Townsend entrance to the park at the southeastern edge of the Tuckaleechee Cove window to the junction with U.S. Highway 441 at park headquarters; U.S. Highway 441 southward to the crest of the mountains at Newfound Gap; and the nearby Forney Ridge parking area at the end of the spur road to Clingmans Dome. Most of these descriptive notes and the accompanying sketches are taken from a guidebook to the geology of the park area (Hadley and others, 1955).

Townsend entrance to Great Smoky Mountains National Park

Just northwest of the entrance to the park on Tennessee Highway 73, a cut 900 feet long exposes rocks of the Ocoee Series (Metcalf Phyllite of the Snowbird Group) and the Ordovician System in contact along the Great Smoky fault (fig. 4). The main fault ( $A$ of fig. 4 ) is obscurely exposed at the southeast end of the cut and rises at a low angle into the slope above. The following features deserve notice:

1. The Metcalf Phyllite above the Great Smoky fault consists of chloritic and sericitic sandy phyllite, whereas the shale beneath, of Middle Ordovician age, has been slickensided and crumpled but contains no metamorphic minerals. The fault thus marks a metamorphic discontinuity, which indicates that the metamorphism of the Metclalf took place before it was thrust over the Ordovician rocks.

2. Between the overriding phyllite and the shale, intensely fractured and crushed blue-gray limestone, 5-25 feet thick, forms one of the several higher slices of the Lower Ordovician part of the Knox Group that were dragged along the sole of the fault. The Knox Group also occurs in normal stratigraphic order beneath shale, sandstone, and limestone at the northwest end of the cut.

3. Exposures high at the northwest end of the cut indicate that bedding in the Middle Ordovician shale and sandstone is disharmonious with that of the limestone below, although the one lies in normal stratigraphic order on the other. This indicates that these rocks are separated by a zone of movement (line $C$, fig. 4) which developed during emplacement of the main thrust above.

4. The overridden Ordovician rocks are cut by a series of normal faults which dip steeply southeast; whether these faults also break the Great Smoky fault above cannot be determined. One of them, which drops shale against limestone, is well displayed near the middle of the cut.
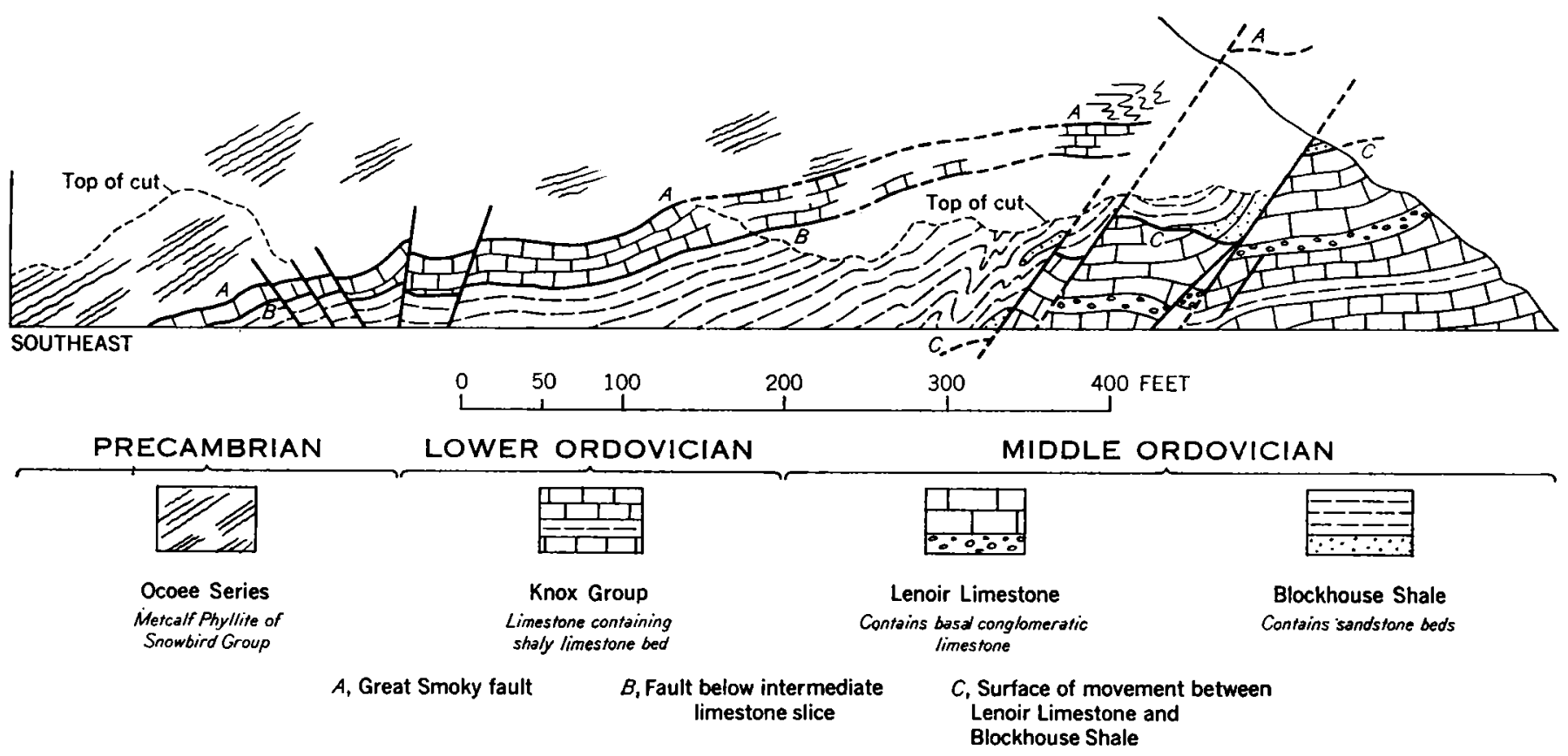

FIGURE 4.-The Great Smoky fault and related structures in cuts on Tennessee Highway 73 at Townsend entrance to the Great Smoky Mountains National Park. 
The Sinks

At The Sinks there is a bridge over the Little River where it drops abruptly through a series of cascades and whirlpools cut in a rock gorge. The Sinks are not a feature of limestone solution as the name might suggest. The abrupt increase in the gradient of the river results from its cutting through an old meander neck; a former course of the river may be traced around the rock knob just southeast of the bridge (fig. $5 A$ ).

The rock at The Sinks is thick-bedded sandstone of the Thunderhead Sandstone. Beds dip southeast but are overturned, as indicated by inverted graded bedding in the sandstone and by the weak cleavage in the slate interbeds, which dips at a lower angle than the bedding (fig. $5 B)$.
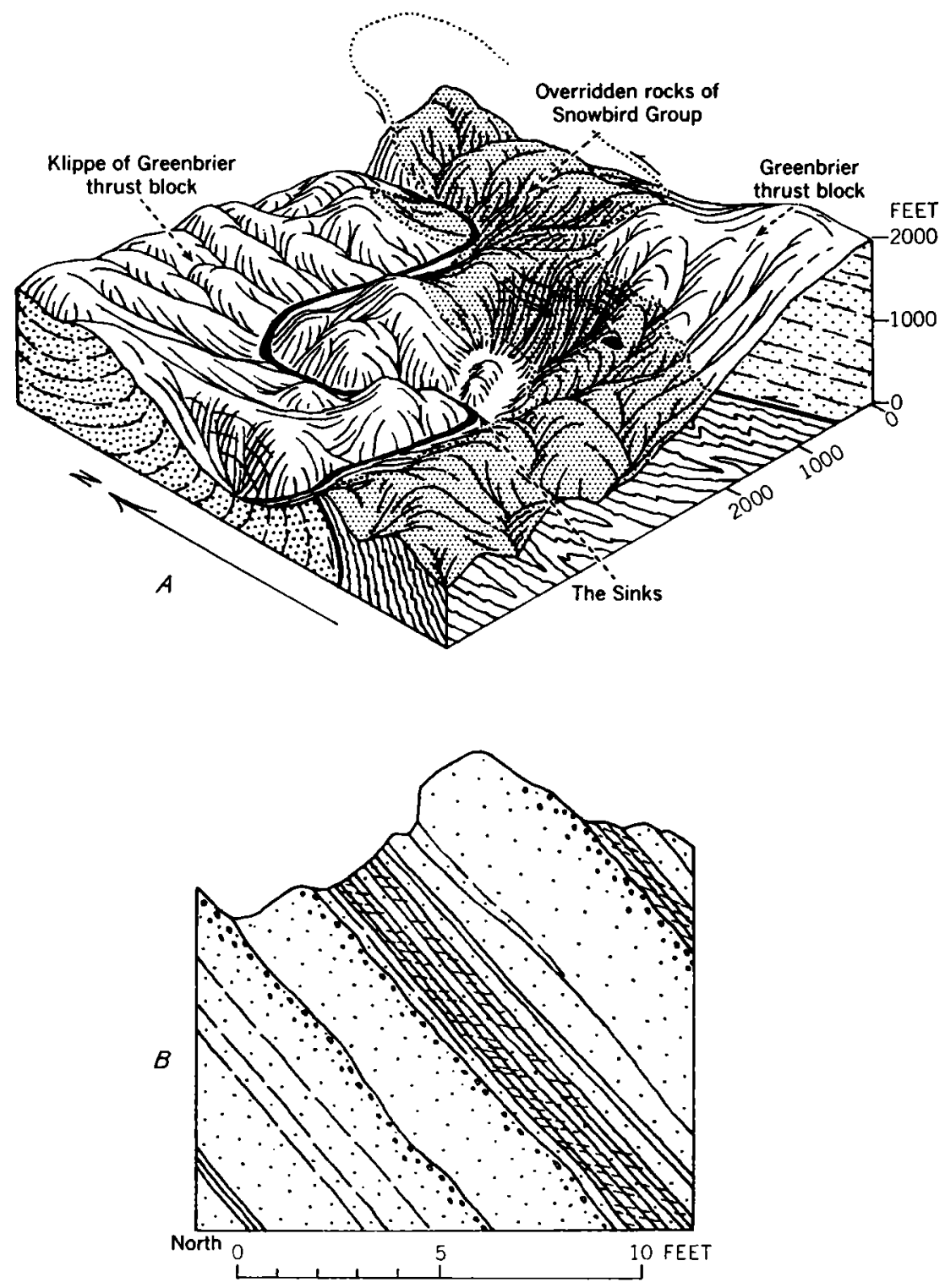

Figure 5.-Geologic features at The Sinks on Tennessee Highway 73 at Blount-Sevier County line. $A$, Block diagram showing cutoff meander neck of Little River, and interpretation of Thunderhead Sandstone as an infolded detached part (klippe) of the Greenbrier thrust block. Drawing by Philip B. King. $B$, Sketch of outcrops at bridge, showing overturned beds as indicated by graded bedding and the low dip of cleavage in slate beds compared with steep dip of beds. Drawing by H. W. Ferguson and Philip B. King. 
Structurally, these rocks are part of a klippe-a detached downfaulted and folded segment of the Greenbrier thrust sheet.

\section{Maloney Point}

This locality affords one of the finest panoramas in the Great Smoky Mountains. Mount Le Conte, which towers to the east above the observer, has an altitude of 6,593 feet, 1 mile higher than the town of Gatlinburg, which is hidden in the hills to the north (fig. 6).

The topography in this view reflects the bedrock structure. The steep face of Mount Le Conte is formed of rocks of the Great Smoky Group, and the trace of the
Greenbrier fault on which they lie is near the base of the slope (fig. 6). The lower ridges to the north are carved from the less massive rocks of the Snowbird Group.

The trace of the Greenbrier fault extends toward Fighting Creek Gap, but it is cut off below the overlook by the Gatlinburg fault. Erosion of crushed and fractured rocks along the trace of the latter has produced Fighting Creek Gap and the straight trenchlike course of Fighting Creek to the east. Cove Mountain, north of Fighting Creek, is formed of rocks of the Great Smoky Group in a part of the Greenbrier thrust sheet that lies on the downthrown side of the Gatlinburg fault.
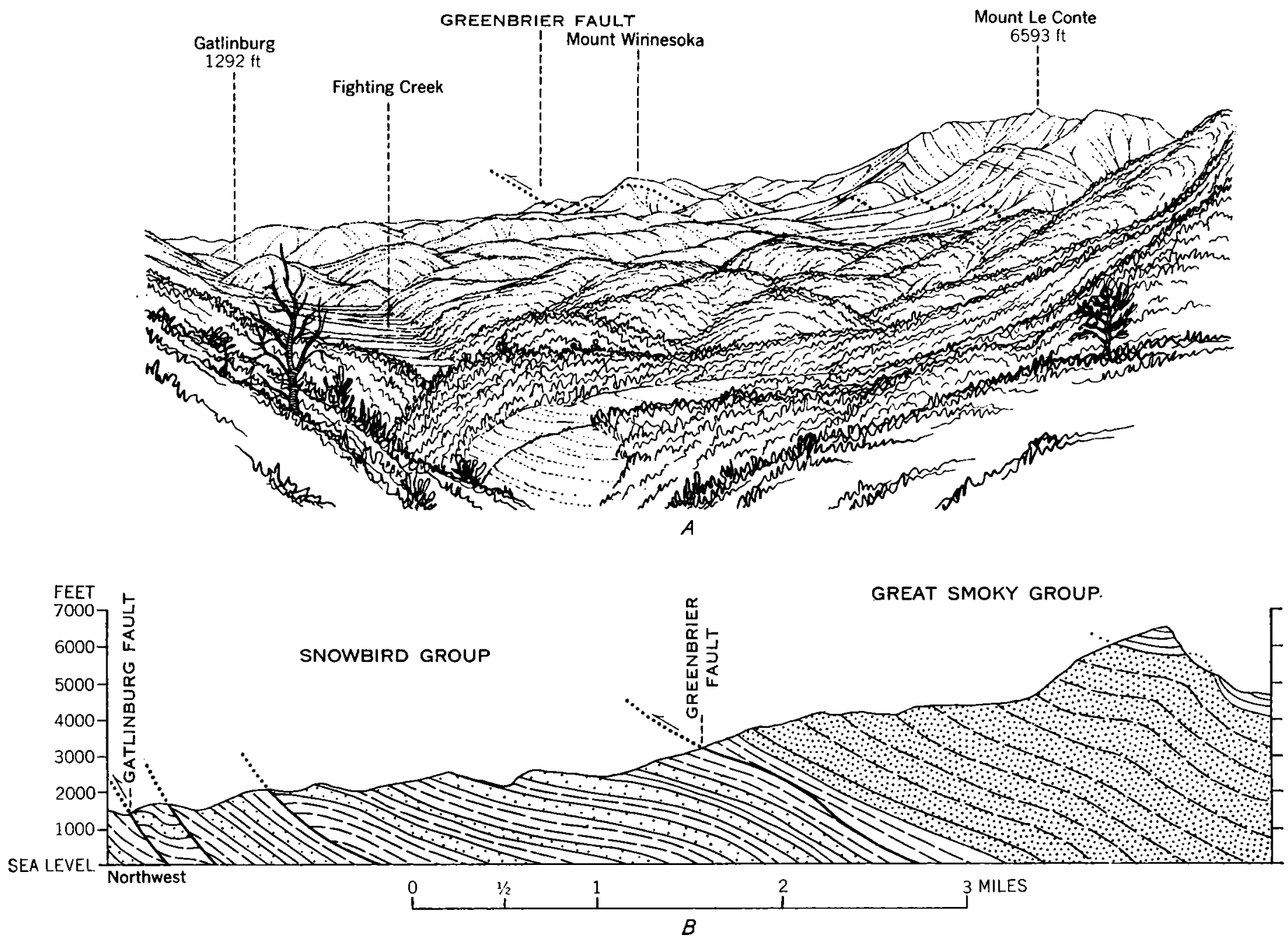

FIgURE 6.-Geologic features visible from Maloney Point on Tennessee Highway 73 a little east of Fighting Creek Gap. $A$, All the rocks encompassed in this view belong to the Ocoee Series: Mount Winnesoka is supported by the Elkmont Sandstone of the Great Smoky Group, and the other high mountains to the right (south) are supported by the overlying Thunderhead Sandstone and Anakeesta Formation. The trace of the Greenbrier fault lies at the base of the steep slopes from Mount Winnesoka to the foreground, and the Roaring Fork Sandstone of the Snowbird Group crops out on the foreground ridges. The Gatlinburg fault follows the valley of Fighting Creek on the left. Drawing by Philip B. King. $B$, Geologic section approximately along skyline of panorama. 
Chimneys Overlook

Outcrops of sandstone and interbedded slate in the long series of roadcuts across the highway from the lookout are typical of the Thunderhead Sandstone of the Great Smoky Group. Graded bedding is the dominant structure, although crossbedding can be seen at a few places. At the base of some beds are indications of erosion of the underlying bed. A few beds show complete gradation, beginning at the base with poorly sorted quartz-feldspar conglomerate, passing upward through coarse sandstone, medium- to fine-grained sandstone, and slaty siltstone to fine-grained slate. In many beds, however, the initial conglomerate and concluding slate are absent. Slate fragments in the upper parts of some graded beds represent layers of mud disrupted by movement of the associated unconsolidated sand. Scour-and-fill structure associated with graded bedding, is not common in these rocks, but is well displayed on a large joint face at the bend in the highway near the lower end of the cuts (fig. $7 B$ ).

In about 800 feet of beds exposed along the highway, the following proportion of rock types is present: quartzfeldspar conglomerate, 6 percent; coarse poorly sorted feldspathic sandstone, 24 percent; medium- and finegrained feldspathic sandstone, 60 percent; slaty siltstone, 9 percent; and slate, 1 percent.

The coarser grained rocks are composed largely of quartz and microcline, with minor amounts of sodic plagioclase, muscovite, biotite, iron ores, and carbonate. The slate consists of muscovite, potash feldspar, quartz, some iron oxides, and a little carbon.

Across the valley of the West Fork of the Little Pigeon River are the two sharp peaks of The Chimneys (fig. 7 $A$ ), whose upper parts are composed of carbonaceous phyllite of the Anakeesta Formation lying conformably on the Thunderhead Sandstone.

Walker Camp Prong

The Anakeesta Formation is exposed in the streambed and in roadcuts along the highway. The formation here includes beds of coarse-grained sandstone, siliceous dolomite, and intraformational conglomerate, as well as the dark pyritic phyllite that is characteristic of the formation. These exposures are near the trough of a large synclinorium and show several minor folds with a steep easterly plunge. Southeast-dipping cleavage in the slaty beds is locally crenulated by a later deformation. The rocks are within the almandine garnet zone of metamorphism, but megascopically visible garnets are rare. Newfound Gap

From this point at the crest of the Great Smoky Mountains one may look across the Oconaluftee fault-line valley to the southern ridges of the Great Smoky Mountains, with the Plott Balsam Range (S. $40^{\circ}$ E. to S. $65^{\circ}$ E.), Bryson City (due south), and Clingmans Dome (S. $52^{\circ}$ W.) in the distance. The rocks exposed in the nearby roadcuts are interbedded sandstone and phyllite of the Anakeesta Formation of the Great Smoky Group; the beds are overturned toward the northwest on the southeast limb of the Alum Cave syncline.

Forney Ridge

The rocks exposed at the parking area are thick beds of feldspathic sandstone of the Thunderhead Sandstone and some interbedded finer grained rocks. Beds dip $25^{\circ}-35^{\circ} \mathrm{SSE}$., and graded bedding at the east end of the parking area indicates that they are right-side up. The sandstone contains many subspherical calcareous concretions; there are also joints filled with quartz and siderite. 

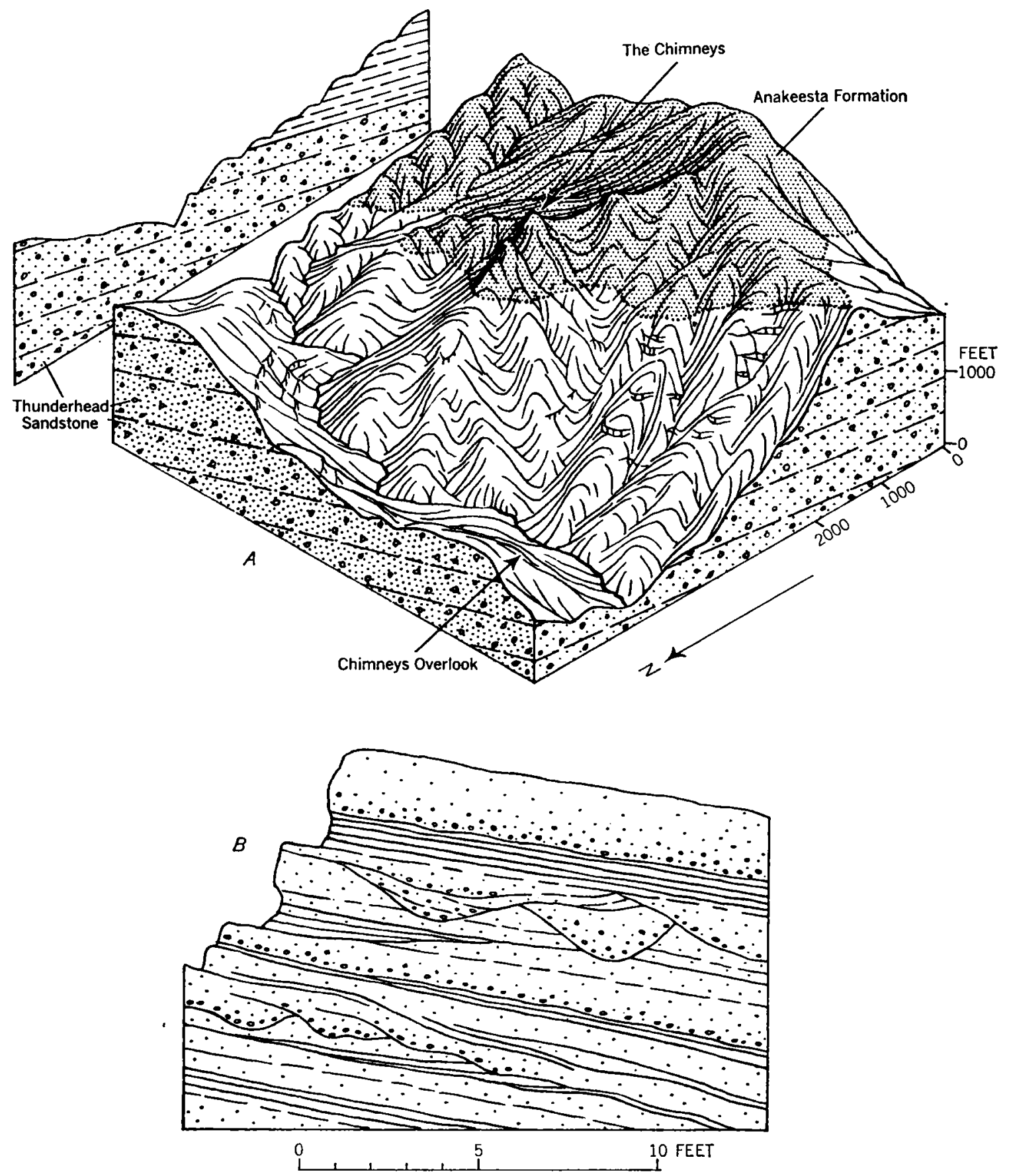

Figure 7.-Geologic features at Chimneys Overlook, on U.S. Highway 441, 7 miles south of Gatlinburg, Tenn. $A$, Block diagram of The Chimneys showing Thunderhead Sandstone overlain by the Anakeesta Formation. $B$, Sketch of part of roadcut showing graded bedding and channeling in feldspathic sandstone of the Thunderhead Sandstone. Drawings by Philip B. King. 


\section{Glossary}

Amphibolite

Anticline

Anticlinorium

Argillaceous

Argillite

Arkose

Augen structure

Basement

Bedrock

Cambrian

Clastic

Cleavage

Competent

Conformable

Crystalline

Current bedded

Debris

Deformation

Detrital
A metamorphic rock composed largely of amphibole and feldspar.

A fold or arch of stratified rocks in which the strata dip in opposite directions from a common ridge or axis.

A large anticline composed of smaller anticlines and synclines.

Clayey; containing clay minerals or their metamorphic products.

Dark fine-grained rock without cleavage or schistosity, resulting from low-grade metamorphism of claystone or mudstone.

A sandstone containing at least 25 percent feldspar usually derived from erosion of granitic rocks.

"Eyes" or knots of mineral or rock fragments around which foliation or flaser structure is strongly bent.

A rock mass, usually igneous or metamorphic on which younger rocks have been deposited.

Solid rock underlying weathered or transported material.

The first period of the Paleozoic Era, from 500 to 600 million years ago.

A term applied to rocks composed of fragmental material derived from preexisting rocks.

The tendency for rocks to split along definite planes which generally have no relation to bedding.

A term applied to rocks capable of sustaining stress without being greatly deformed.

Describes strata deposited without significant disturbance or removal of previously deposited strata.

A term applied to rocks composed wholly of crystalline mineral grains; that is, igneous and metamorphic rocks as distinct from sedimentary rocks.

Shows bedding features (crossbedding or ripple mark) indicating deposition by currents of water.

Rock and mineral fragments produced by weathering of rocks. Synonymous with detritus.

Change of shape or attitude of a rock body by folding, shearing, fracturing, compression, etc.

Composed of detritus or debris.
Detritus

Devonian

Dip angle

Dolomite

Erosion

Fault

Fauna

Feldspathic

Flaser structure

Flora

Foliation

Formation

Geosyncline

Gneiss

Grade (of metamorphic rocks)

Granite

Granitic

Granitization
See Debris.

The fourth period of the Paleozoic Era, from 350 to 400 million years ago.

The angle that a tilted or folded rock layer makes with a horizontal surface. A rock composed essentially of the mineral dolomite or ( $\mathrm{CaMg}$ ) $\mathrm{CO}_{3}$.

The process of disintegration and removal of the rocks at the earth's surface by weathering and moving water, wind, ice, or landslide.

A fracture in the earth's crust along which rock on one side has been displaced relative to rock on the other.

The animal life existing at a particular time or locality.

Containing feldspar as a principal ingredient.

Lenses of granular material separated by wavy ribbons and streaks of finely crystalline foliated material.

The plant life existing at a particular time or locality.

Parallel alinement of platy mineral grains or flattened aggregates in a metamorphosed or sheared rock.

A distinctive bed or group of beds selected from a succession of strata for convenience in mapping, description, and reference.

An elongate depositional basin of continental proportions which is filled by sedimentary rocks over a long period of geologic time.

A visibly crystalline metamorphic rock possessing mineral layering or foliation but not easily split along foliation surfaces.

Refers to the pressure-temperature conditions (low, medium, or high) at which metamorphism occurred.

In the strict sense, a visibly grained igneous rock composed essentially of alkali feldspars and quartz. Commonly, any rock of this composition and texture, whether igneous or metamorphic in origin.

Pertaining to granite, or similar to granite in composition or texture.

Metamorphic transformation of nongranitic rocks to granitelike rocks. 
Granodiorite

Homocline

Igneous

Intercalated

Interglacial

Intrusive

Klippe

Laminae

Magma

Massive

Megascopic

Metamorphic

Metamorphism

Mississippian

Ordovician

Paleozoic

Pegmatite

Phyllite

Plutonic

Precambrian

Quartz

monzonite
A granitic rock in which soda-lime feldspar is at least twice as abundant as potassium feldspar.

Rock strata which are tilted uniformly in the same direction.

A term applied to rocks formed by crystallization or solidification from natural silicate melts, generally at temperatures between $600^{\circ} \mathrm{C}$ and $1000^{\circ} \mathrm{C}$.

A body of material interbedded or interlaminated with another.

The time between major advances of continental glaciers.

A term for rocks, especially igneous rocks, that have penetrated other rocks.

Part of a thrust sheet isolated by erosion from the remainder of the sheet.

Thin rock layers, generally less than $1 \mathrm{~cm}$ thick, of sedimentary or other origin.

A hot mobile silicate mixture of crystals and melt within the earth's crust.

A term applied to thick bodies of homogenous rock uninterrupted by bedding surfaces, fractures, or other mechanical discontinuities.

Visible with the unaided eye or with a hand lens.

Pertaining, to or resulting from, metamorphism.

The process whereby sedimentary or igneous rocks have been altered by heat and pressure accompanying deep burial in the earth's crust.

The fifth period of the Paleozoic Era, from 310 to 350 million years ago.

The second period of the Paleozoic Era, from 430 to 500 million years ago.

The second era of geologic time, from 225 to 600 million years ago.

Igneous rock of unusually coarse or varied texture occurring in intrusive bodies generally a few feet to a few hundred feet long.

A metamorphic rock similar to schist but finer grained, so that the constituent grains cannot be seen with the unaided eye.

A term applied to rocks and processes occurring deep within the earth's crust. Geologic time before the Paleozoic Era.

A granitic rock in which the proportions of potassium feldspar and soda-lime feldspar are more or less equal.
Quartzite

Radioactive

Recrystallization

Schist

Sedimentary

Sequence

Sill

Slickensides

Slip

Stratified

Strike

Syncline

Synclinorium

Tectonic

Thrust fault
A sedimentary or metamorphic rock composed largely of quartz grains cemented by silica.

A term applied to minerals or rocks containing atoms whose nuclei radiate atomic particles and energy.

Alteration of rocks whereby preexisting mineral grains are destroyed and new ones formed, generally by increased heat and pressure; one of the metamorphic processes.

A visibly crystalline metamorphic rock containing abundant mica or other cleavable minerals so alined that the rock breaks regularly along the mineral grains.

A term applied mainly to rocks formed of fragments of other rocks transported from their source and deposited in water. Applies also to material transported in solution and deposited by chemical or organic agents.

A succession of stratified rocks.

A tabular body of igneous rock intruded along the bedding surfaces of stratified rocks.

Grooves or scratches in rocks made by movement along a fault surface.

The amount of movement on a fault measured on the fault surface. Strike slip is the component of slip measured along the strike of the fault; dip slip is the component measured in the direction of the dip of the fault.

A term applied to rocks deposited in nearly horizontal layers or strata on the earth's surface.

The direction or bearing of a horizontal line on a sloping bed, fault, or other rock surface.

A fold in stratified rocks in which the strata on opposite sides usually dip inward toward each other.

A large syncline composed of smaller synclines and anticlines.

Pertaining to the larger structural features of the earth's crust and the forces that have produced them.

A fault, commonly of low dip, on which rocks have slid or have been pushed laterally over other rocks. 
Turbidity current A heavy mixture of sediment and water that flows along the sea bottom in response to gravity.

Window

A hole produced by erosion through a thrust fault exposing the underlying rocks.

\section{References Cited}

Carroll, Dorothy, Neuman, R. B., and Jaffe, H. W., 1957, Heavy minerals in arenaceous beds in parts of the Ocoee Series, Great Smoky Mountains, Tennessee: Am. Jour. Sci., v. 255, no. 3, p. 176-193.

Cattermole, J. M., 1955, Geology of the Shooks Gap quadrangle, Tennessee: U.S. Geol. Survey Geol. Quad. Map GQ-76, scale $1: 24,000$.

1962, Geology of the Maryville quadrangle, Tennessee: U.S. Geol. Survey Geol. Quad. Map GQ-163, scale $1: 24,000$.

Espenshade, G. H., 1963, Geology of some copper deposits in North Carolina, Virginia, and Alabama: U.S. Geol. Survey Bull. 1142-I, 50 p.

Ferguson, H. W., and Jewell, W. B., 1951, Geology and barite deposits of the Del Rio district, Cocke County, Tennessee: Tennessee Div. Geology Bull. 57, 235 p.

Hadley, J. B., 1964, Correlation of isotopic ages, crustal heating, and sedimentation in the Appalachian region, in Lowry, W. D., ed., Tectonics of the southern Appalachians: Virginia Polytech. Inst., Dept. Geol. Sci. Mem. 1, p. 33-45.

Hadley, J. B., and Goldsmith, Richard, 1963, Geology of the eastern Great Smoky Mountains, North Carolina and Tennessee: U.S. Geol. Survey Prof. Paper 349-B, p. B1-B118.

Hadley, J. B., King, P. B., Neuman, R. B., and Goldsmith, Richard, 1955, Outline of the geology of the Great Smoky Mountains area, Tennessee and North Carolina, in Russell, R. J., ed., Guides to southeastern geology: Geol. Soc. America [Guidebook], Ann. Mtg., New Orleans, La., 1955, p. 390-427.

Hamilton, W. B., 1961, Geology of the Richardson Cove and Jones Cove quadrangles, Tennessee: U.S. Geol. Survey Prof. Paper 349-A, p. A1-A55.

Hurst, V. J., 1955, Stratigraphy, structure, and mineral resources of the Mineral Bluff quadrangle, Georgia: Georgia Geol. Survey Bull. 63, 137 p.

Keith, Arthur, 1895, Description of the Knoxville sheet [Tennessee-North Carolina]: U.S. Geol. Survey Geol. Atlas, Folio 16, 6 p.

1896, Description of the Loudon sheet [Tennessee]:

U.S. Geol. Survey Geol. Atlas, Folio 25, 6 p.

1907, Description of the Nantahala quadrangle [North Carolina-Tennessee]: U.S. Geol. Survey Geol. Atlas, Folio 143, 11 p.
King, P. B., 1964, Geology of the central Great Smoky Mountains, Tennessee: U.S. Geol. Survey Prof. Paper 349-C, p. C1-C148.

King, P. B., Hadley, J. B., Neuman, R. B., and Hamilton, W. B., 1958, Stratigraphy of the Ocoee Series, Great Smoky Mountains, Tennessee and North Carolina: Geol. Soc. American Bull., v. 69, no. 8, p. 947-966.

Kulp, J. L., and Eckelmann, F. D., 1961, Potassium-argon isotopic ages on micas from the southern Appalachians: New York Acad. Sci. Annals, v. 91, art. 2, p. 408-419. Laurence, R. A., and Palmer, A. R., 1963, Age of the Murray Shale and Hesse Quartzite on Chilhowee Mountain, Blount County, Tennessee: U.S. Geol. Survey Prof. Paper 475-C, p. C53-C54.

Long, L. E., Kulp, J. L., and Eckelmann, F. D., 1959, Chronology of major metamorphic events in the southeastern United States: Am. Jour. Sci., v. 257, no. 8, p. $585-603$.

Neuman, R. B., 1951, The Great Smoky fault: Am. Jour. Sci., v. 249 , no. 10 , p. $740-754$.

1955, Middle Ordovician rocks of the Tellico-Sevier belt, eastern Tennessee: U.S. Geol. Survey Prof. Paper 274-F, p. F141-F178.

1960, Geology of the Wildwood quadrangle, Tennessee: U.S. Geol. Survey Quad. Map GQ-130, scale $1: 24,000$.

Neuman, R. B., and Nelson, W. H., 1965, Geology of the western part of the Great Smoky Mountains, Tennessee: U.S. Geol. Survey Prof. Paper 349-D, p. D1-D81.

Neuman, R. B., and Wilson, R. L., 1960, Geology of the Blockhouse quadrangle, Tennessee: U.S. Geol. Survey Geol. Quad. Map GQ-131, scale 1:24,000.

Oriel, S. S., 1950, Geology and mineral resources of the Hot Springs window, Madison County, North Carolina: North Carolina Div. Mineral Resources Bull. 60, 70 p.

Resser, C. E., 1938, Cambrian system (restricted) of the southern Appalachians: Geol. Soc. America Spec. Paper 15, 140 p.

Rodgers, John, 1953, Geologic map of East Tennessee with explanatory text: Tennessee Div. Geology Bull. 58, pt. 2, $168 \mathrm{p}$.

Safford, J. M., 1869, Geology of Tennessee: Nashville, Tenn. [Tennessee General Assembly], 550 p.

Stern, T. W., and Rose, H. J., Jr., 1961, New results from lead-alpha measurements: Am. Mineralogist, v. 46, p. 606-612.

Tilton, G. R., Wetherell, G. W., Davis, G. L., and Bass, M. N., 1960, 1000-million-year-old minerals from the eastern United States and Canada: Jour. Geophys. Research, v. 65 , no. 12 , p. $4173-4179$.

Walcott, C. D., 1890, The fauna of the Lower Cambrian or Olenellus zone: U.S. Geol. Survey 10th Ann. Rept., pt. 1, p. 509-763. 


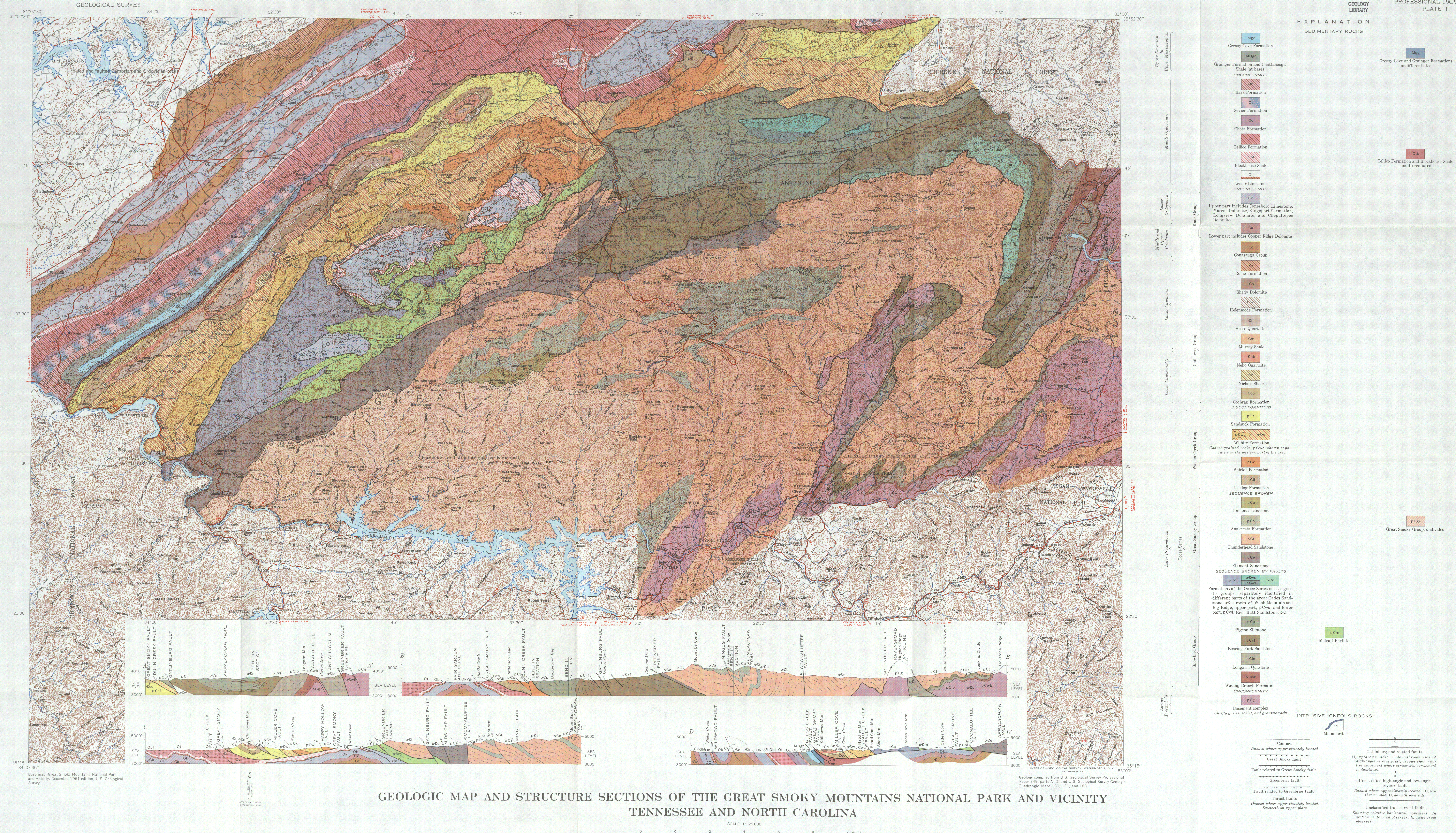
